\title{
Viruses of foodborne origin: a review
}

\author{
This article was published in the following Dove Press journal: \\ Virus Adaptation and Treatment \\ 29 April 2015 \\ Number of times this article has been viewed
}

\section{Ewen CD Todd ${ }^{1,2}$ Judy D Greig ${ }^{3}$}

'Ewen Todd Consulting LLC, Okemos, MI, USA; ${ }^{2}$ Department of Nutrition and Food Science, Faculty of Agricultural and Food Sciences, American University of Beirut, Beirut, Lebanon; ${ }^{3}$ Division of Public Health Risk Sciences, Laboratory for Foodborne Zoonoses, Public Health Agency of Canada, Guelph, ON, Canada
Correspondence: Ewen Todd Department of Nutrition and Food Science, Faculty of Agricultural and Food Sciences, American University of Beirut, PO Box II-0236, Riad El Solh, Beirut I I07-2020, Lebanon

Tel +96 I I 350000 ext 4549

Fax +96 I I 744460

Email todde@msu.edu
Abstract: Enteric viruses are major contributors to foodborne disease, and include adenovirus, astrovirus, rotavirus, sapovirus, hepatitis $\mathrm{A}$ and $\mathrm{E}$ viruses, and norovirus. From a foodborne transmission perspective, norovirus is the most important; however, hepatitis A is associated with more serious illness. Foodborne viruses are transmitted through contaminated food, but also in combination with person-to-person contact or through environmental contamination. These viruses survive well in the environment, are excreted in abundance in feces, and have a low infectious dose, all of which facilitate spread within a community. Many colonized individuals experience mild gastroenteritis lasting a few days or are asymptomatic, although viral excretion may continue over days or weeks. Severe illness tends to be restricted to the very young and elderly, especially in closed communities such as schools and homes for the aged. In the USA, norovirus is considered to be responsible for two thirds of all foodborne illnesses occurring in a wide range of institutional settings, including schools, colleges, child care centers, cruise ships, prisons, and soldiers on campaign. Norovirus outbreaks also occur at one-time events, such as banquets, wedding receptions, birthday parties, and potluck meals, and are most often introduced by infected food workers producing, preparing, or serving food, or through self-service buffets. Often the infections are introduced from the community into institutions where they can infect the majority of residents unless quickly controlled. In countries where economic assessments have been completed, there is a high cost for prevention, control, and treatment of infections. Control measures are limited, but include proper clean-up and disinfection after vomiting or diarrhea, and prevention of food contact by infected individuals. As diagnostics improve, more foodborne illnesses relating to enteric viruses are expected to be identified, especially in developing countries where there are little data today.

Keywords: foodborne, enteric viruses, shellfish, food workers, prevention, control, ready-toeat food

\section{Introduction}

Foodborne viruses are transmitted via contaminated food, but also in combination with person-to-person contact or via contamination of the environment, eg, water. ${ }^{1}$ These viruses include human adenovirus (HAdV), human astrovirus (HAstV), norovirus (NoV), and human rotavirus (HRV), which infect parts of the intestinal tract, eg, the epithelial lining of the duodenum. Hepatitis A and E viruses (HAV and HEV) enter the bloodstream through the epithelium and from there to the liver hepatocytes and macrophages. ${ }^{2,3}$ The pathology of sapovirus $(\mathrm{SaV})$ and Middle East respiratory syndrome coronavirus (MERS-CoV) have not been well described. There are no known foodborne outbreaks from enteroviruses. From the limited available information, foodborne viruses have a low infectious dose and are dispersed in stool or emesis in 
high numbers (up to $10^{11}$ particles per gram of stool). ${ }^{1}$ Food contaminated by fecal sources, such as shellfish harvested in polluted waters, fruits, and vegetables irrigated with water containing sewage or picked by infected workers, and readyto-eat foods prepared by infected handlers are means of infection. Enteric viruses cannot multiply in food or water, but are generally very environmentally stable outside the host and are acid-resistant. ${ }^{1}$ There has been limited success growing human enteric viruses in cell culture, mainly primate cells, but culturable surrogates for human viruses such as feline and murine caliciviruses for $\mathrm{NoV}$ and porcine enteric calicivirus for $\mathrm{SaV}$ are used for research. Enzyme-linked immunosorbent assay and reverse transcriptase polymerase chain reaction (RT-PCR) assays are used for routine detection in clinical specimens. International Organization for Standardization Technical Specification 15216:2013 ${ }^{4}$ describes a method for quantification of levels of HAV and NoV genogroup I (GI) and II (GII) RNA from test samples of foods, food surfaces, or food contact surfaces; target sequences within the viral RNA are amplified and detected by RT-PCR. This approach can be used for other human viruses after appropriate validation and using target-specific primer and probe sets. NoV and HAV are considered to be the main foodborne viruses of concern, ${ }^{1}$ but as surveillance improves, other enteric viruses may be considered as emerging foodborne pathogens. The very young and elderly are more likely to be severely affected and have a high propensity for recurrent infectious intestinal illness. ${ }^{5}$ The characteristics of viruses that have been implicated in foodborne disease are listed in Table 1.

\section{Foodborne virus outbreaks}

During the past century, most foodborne disease illnesses were attributed to bacterial pathogens; however, with better diagnostic technology and investigative epidemiology, it is now accepted that some enteric viruses are major contributors as well. However, some of these are only transmitted by food occasionally. For instance, Scallan et $\mathrm{al}^{6}$ estimated that $<1 \%$ of HAstV, HRV, and $\mathrm{SaV}$ cases are foodborne compared with $7 \%$ for HAV cases and $26 \%$ for NoV cases; only $41 \%$ of HAV and $<1 \%$ of NoV are considered to be travel-related. Since the introduction of HRV vaccines, NoV has become the leading cause of medically attended acute gastroenteritis in US children, and is associated with nearly one million health care visits annually. ${ }^{7}$ In Canada, NoV causes the greatest number of foodborne illnesses, accounting for $65 \%$ of the estimated 1.6 million cases reported for 30 known pathogens from 2000 to $2010 .{ }^{8}$ Other enteric viruses represent relatively few cases: SaV, 0.59\%; HRV, 0.26\%; adenovirus, $0.23 \%$; HAstV, $0.12 \%$; and HAV, $0.02 \%$. These percentages are very similar to those of Scallan et al, ${ }^{6}$ who estimated that there were 9.4 million foodborne illnesses caused by 31 pathogens in the USA, of which $58 \%$ were caused by NoV; other viruses were much lower (SaV, HRV, and AstV each at $0.16 \%$, and HAV at $0.02 \%$ ). These pathogen-specific results are similar to estimates of other countries (Australia, the Netherlands, New Zealand, and France) in that NoV is now considered to be the main contributor to the burden of foodborne diseases, ${ }^{9-12}$ with the proportion foodborne for $\mathrm{NoV}$ ranging from around $11 \%$ in the $\mathrm{UK}^{13}$ to $39 \%$ in New Zealand. ${ }^{11}$

\section{Norovirus}

$\mathrm{NoV}$ is the most frequently reported foodborne pathogen in many countries, although still underestimated. ${ }^{10-14}$ The Centers for Disease Control and Prevention reports that $50 \%$ of foodborne outbreaks are attributed to $\mathrm{NoV}^{15} \mathrm{NoV}$ causes an estimated one in 15 US residents to become ill annually as well as 56,000-71,000 hospitalizations and 570-800 deaths, predominantly among young children and the elderly. Studies in the UK and the Netherlands showed that NoV was responsible for $3.6 \%{ }^{13}$ and $15.6 \%{ }^{12}$ of foodborne illnesses, respectively. NoV-associated deaths are rare, with an incidence of $0.19-0.40$ deaths per 10,000 population..$^{15}$ Although NoV is often spread through person-to-person contact, foodborne transmission can contribute to widespread exposures, resulting in large outbreaks. Foods commonly involved in NoV outbreaks are leafy greens (such as lettuce), fresh fruits, and shellfish. Most foodborne NoV outbreaks occur in food service settings like restaurants ${ }^{15}$ and large catered events. Infected food workers can transmit NoV by touching readyto-eat foods, such as raw fruits and vegetables, or foods that will not be cooked further, with their bare, inadequately washed hands. Unfortunately, it is not just workers with clinical symptoms who transmit NoV, since asymptomatic food handlers were found to be a major contributor to Danish outbreaks, ${ }^{16}$ where contamination occurred with equal frequency during production, preparation, and serving, and at self-serve buffets. Some of the workers had been in contact with ill household members before handling the food and remained asymptomatic; others developed symptoms shortly after or were post-symptomatic. However, food may be contaminated by NoV at any point during production, shipping, handling, or preparation. NoV outbreaks can result from fecal contamination of foods at their source, eg, oysters harvested from contaminated water, environmental sources with leafy 
greens, and raspberries spray-irrigated with contaminated water. Lettuce has been implicated in many NoV outbreaks, ${ }^{17}$ eg, in Michigan in 2005 after a national submarine sandwich franchise restaurant catered four luncheons with a total of 88 ill. ${ }^{18}$ In Denmark, eleven outbreaks with 260 cases were all linked to lettuce imported from France in 2010. ${ }^{19}$ In Europe in 2012, 14\% of reported foodborne outbreaks were attributed to viruses, predominantly NoV; mixed foods and buffet meals were the main foodborne vehicles, followed by shellfish, vegetables, juices, and bakery products. ${ }^{20}$ Of particular note was a NoV outbreak in Germany associated with frozen Chinese strawberries mainly distributed through one large catering company, with 10,950 people, primarily school/kindergarten children, infected and 38 hospitalized. ${ }^{21}$ The acid resistance of $\mathrm{NoV}$ and $\mathrm{HAV}$ might explain their association with outbreaks where acid fruits were implicated, eg, raspberries. ${ }^{22}$ NoV outbreaks have also been caused by contaminated water from sewage in wells and in recreational water settings, eg, beaches, pools, and lakes. ${ }^{15}$

Over $90 \%$ of diarrheal disease outbreaks on cruise ships are caused by NoV, which is especially challenging to control on ships because of close living quarters, shared dining areas, and rapid turnover of passengers between cruises. ${ }^{23}$ Before embarkation, NoV can be brought on board in contaminated food or water or by passengers who are already infected. Repeated outbreaks on consecutive cruises may result from infected crew or environmental contamination not sufficiently decontaminated since $\mathrm{NoV}$ can persist on surfaces and is resistant to many common disinfectants. Being aware of the risks, crews try to prevent infected persons from boarding using screening procedures, with limited effectiveness. Many cruise ships do not permit buffet self-service until 24-48 or more hours have elapsed after boarding in an attempt to prevent passenger-to-food transmission.

Overall, the burden of NoV illness is high. Recent estimates in the USA showed that NoV illness costs US \$2.0-\$3.7 billion annually, and has led to a loss of approximately 5,000 quality-adjusted life-years, making NoV one of the top five costly pathogens causing foodborne enteric illnesses. ${ }^{24}$ The highest cost associated with 14 foodborne pathogens is also attributed to human NoV in the Netherlands, where foodborne NoV cases resulted in a burden of 275 undiscounted and 194 discounted disability-adjusted life-years in $2009 .{ }^{25} \mathrm{NoV}$ gastroenteritis outbreaks cost the English National Health Service US\$184 million in one year (2002-2003). ${ }^{26}$ This accumulation of evidence underlines the enormous impact of NoV on populations.

\section{Outbreak example: wedding reception}

In October 2012, the provincial public health directorate of Salzburg, Austria, reported a NoV outbreak associated with a mushroom dish among guests at a wedding reception. ${ }^{27}$ Cases and kitchen workers tested positive for NoV GII.4 Sydney. No food safety training was documented for the employees and the kitchen staff's restroom lacked functioning facilities for hand hygiene. The mushroom dish was prepared on the morning of the wedding and reheated just before serving, with parsley added by hand prior to serving. One of the six NoV-positive kitchen workers was ill with diarrhea the day before and the day of the wedding. He cleaned flatware and dinnerware used for the dinner. The outbreak strain possibly entered the kitchen through this symptomatic kitchen worker and spread through hand contact to kitchen surfaces, dishes, and flatware. The epidemiologically associated dish could have been contaminated directly by the asymptomatic kitchen worker when adding the parsley. The mushrooms could also have been contaminated by contact with flatware or dishes, previously contaminated by the symptomatic kitchen worker during cleaning.

\section{Hepatitis A}

Globally, there are an estimated 1.4 million cases of HAV and 200 million asymptomatic carriers annually. ${ }^{28}$ In developed countries, with good sanitary infrastructures, the infection rate is low, and many of these countries have instituted an immunization schedule for children and adults traveling to endemic regions. ${ }^{29} \mathrm{HAV}$ can be transmitted person-to-person, or through contaminated water and food, particularly fruit or ready-to-eat foods that have not been sufficiently heated to inactivate the virus. In non-endemic countries with a low incidence of disease and low vaccine coverage there is a large susceptible population, which regularly receives imported products from HAV-endemic regions. Since some of these products have a long shelf-life, especially if frozen or preserved, the potential is created for extended HAV outbreaks. Frequently when HAV infection has been identified in a food handler, the exposed public is notified and offered immunoglobulin. ${ }^{29}$ Although the addition of sanitizers such as chlorine, peroxyacetic acid, and hydrogen peroxide achieve only a marginal reduction of viruses on fresh produce, they are useful to reduce the likelihood of cross-contamination between wash water and fresh produce. Depuration of bivalve molluscs does not necessarily remove infectious viral particles from the meat; HAV and HRV showed $<2$ $\log$ reduction after 4 days of depuration of experimentally 
Table I Characteristics of the diseases caused by foodborne viruses

\begin{tabular}{|c|c|c|c|c|}
\hline $\begin{array}{l}\text { Virus, discovery } \\
\text { date, classification }\end{array}$ & $\begin{array}{l}\text { Structure } \\
\text { and size }\end{array}$ & $\begin{array}{l}\text { Transmission and } \\
\text { infective dose }\end{array}$ & Survival & $\begin{array}{l}\text { Incubation period } \\
\text { and symptoms }\end{array}$ \\
\hline $\begin{array}{l}\text { NoV, I } 968 \text { (Norwalk } \\
\text { virus); single-stranded } \\
\text { RNA, non-enveloped } \\
\text { viruses in the genus } \\
\text { Norovirus, family } \\
\text { Caliciviridae; five NoV } \\
\text { genogroups (GI-GV) } \\
\text { have been described, } \\
\text { of which only GI and } \\
\text { Gll, and more rarely } \\
\text { GIV, infect humans } \\
\text { Nine genotypes have } \\
\text { been proposed within } \\
\text { Gl and } 22 \text { within GIl, } \\
\text { with Gll.4 (Lordsdale) } \\
\text { being the most } \\
\text { prevalent genotype } \\
\text { worldwide in epidemics } \\
\text { Several new genogroup } \\
\text { variants can occur } \\
\text { during epidemics }\end{array}$ & $\begin{array}{l}\text { Single-stranded } \\
\text { RNA genome of } \\
7.3-7.6 \mathrm{~kb} \text {, with a } \\
\text { diameter of } \\
28-35 \mathrm{~nm}\end{array}$ & $\begin{array}{l}\text { Fecal-oral; epithelial cells } \\
\text { invaded; < } 100 \text { viral particles }\end{array}$ & 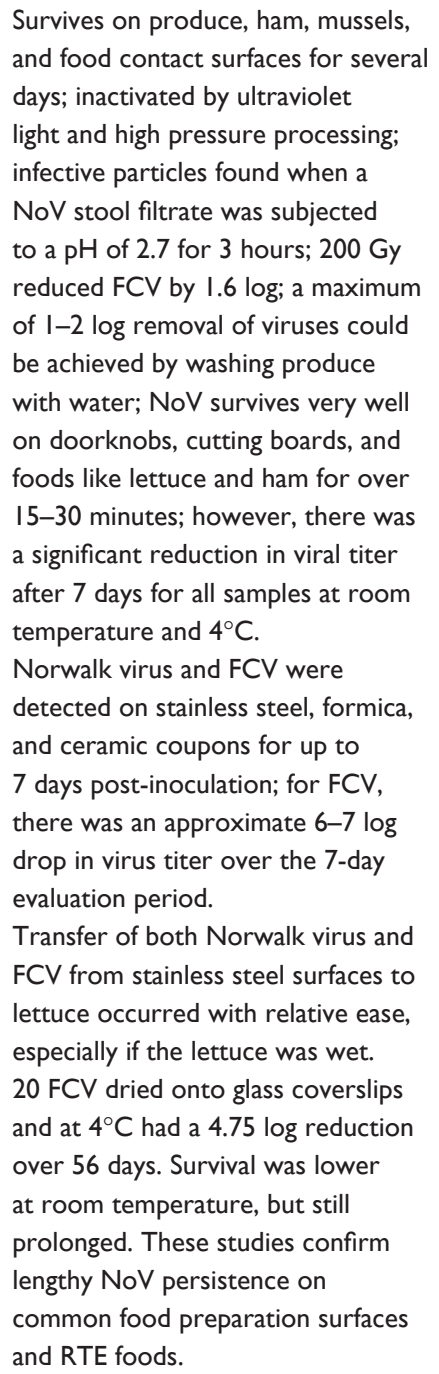 & $\begin{array}{l}0.5-3 \text { days. } \\
\text { Nausea, vomiting (often } \\
\text { projectile), diarrhea, and } \\
\text { abdominal pain, sometimes } \\
\text { headache, myalgia, } \\
\text { and low-grade fever; } \\
\text { immunocompromised at } \\
\text { greatest risk for severe } \\
\text { infection; hospitalizations } \\
\text { and deaths more likely in } \\
\text { outbreaks associated with } \\
\text { Gll.4 viruses }\end{array}$ \\
\hline $\begin{array}{l}\text { HAV, I973; genus } \\
\text { Hepatovirus, family } \\
\text { Picornaviridae; one } \\
\text { serotype and seven } \\
\text { different genetic } \\
\text { groups (four humans } \\
\text { and three simian); six } \\
\text { human subtypes have } \\
\text { been described (IA, IB, } \\
\text { IIA, IIB, IIIA, IIIB); most } \\
\text { human isolates are of } \\
\text { genotype IA; } \\
\text { Genotype III has } \\
\text { been isolated from } \\
\text { both humans and owl } \\
\text { monkeys }\end{array}$ & $\begin{array}{l}\text { Icosahedral, non- } \\
\text { enveloped virus } \\
\text { with a diameter of } \\
27-32 \mathrm{~nm}\end{array}$ & $\begin{array}{l}\text { Fecal-oral; HAV enters the } \\
\text { bloodstream through the } \\
\text { epithelium of the oropharynx } \\
\text { or intestine. The blood carries } \\
\text { the virus to the liver, where it } \\
\text { multiplies within hepatocytes } \\
\text { and macrophages. Virions } \\
\text { are secreted into the bile and } \\
\text { released in stool. } \\
\text { The infectious dose is } 10-100 \\
\text { viral particles }\end{array}$ & $\begin{array}{l}\text { HAV is resistant to pH I and } \\
\text { survives for one hour at } 60^{\circ} \mathrm{C} \text {. } \\
\text { HAV appears to be relatively } \\
\text { resistant to free chlorine, especially } \\
\text { when the virus is associated with } \\
\text { organic matter; it persists in dried } \\
\text { feces, the environment, produce, } \\
\text { mussels, and on food contact } \\
\text { surfaces for a month at room } \\
\text { temperature. HAV on lettuce } \\
\text { survives at } 4{ }^{\circ} \mathrm{C} \text { for up to I } 2 \text { days } \\
\text { in ambient air and under various } \\
\text { modified atmospheric conditions } \\
\text { HAV is stable for } 90 \text { days on } \\
\text { frozen raspberries, blueberries, } \\
\text { strawberries, parsley, and basil }\end{array}$ & $\begin{array}{l}\text { 2-4 weeks ( } 15-50 \text { days) } \\
\text { Acute, not chronic infection, } \\
\text { characterized by sudden } \\
\text { onset of fever, malaise, } \\
\text { nausea, anorexia, fatigue, } \\
\text { and abdominal discomfort, } \\
\text { followed in several days by } \\
\text { jaundice. Asymptomatic or } \\
\text { mild infections frequent, } \\
\text { but typically foodborne } \\
\text { HAV is a much more severe } \\
\text { and long-lasting illness } \\
\text { than gastroenteritis; high } \\
\text { mortality with fulminant } \\
\text { hepatitis, especially in } \\
\text { immunocompromised } \\
\text { persons }\end{array}$ \\
\hline
\end{tabular}




\begin{tabular}{|c|c|c|c|c|c|}
\hline $\begin{array}{l}\text { Duration and } \\
\text { therapy }\end{array}$ & Shedding & Prevention and control & $\begin{array}{l}\text { Detection } \\
\text { methods }\end{array}$ & $\begin{array}{l}\text { Outbreaks and food } \\
\text { implicated }\end{array}$ & References \\
\hline $\begin{array}{l}\text { 2-3 days } \\
\text { ( } 2 \text { weeks); } \\
\text { Typically mild, } \\
\text { self-limiting }\end{array}$ & $\begin{array}{l}\text { Shed in stools and } \\
\text { vomitus, lasting I0 or } \\
\text { more ( } 28 \text { ) days; } \\
30 \text { million virus particles } \\
\text { can be expelled in a } \\
\text { single vomiting incident; } \\
\text { the shedding of virus } \\
\text { in stools begins before } \\
\text { onset of symptoms } \\
\text { (prodromal stage), } \\
\text { typically peaks (at about } \\
\text { I0'0 viral particles per } \\
\text { gram of stool) on day } 4 \\
\text { following exposure, } \\
\text { and may persist for } \\
\text { many weeks in the } \\
\text { general population, } \\
\text { or for months in } \\
\text { immunocompromised } \\
\text { individuals and very } \\
\text { young children; } \\
\text { in children, NoV } \\
\text { gastroenteritis tends to } \\
\text { be less severe than HRV } \\
\text { gastroenteritis }\end{array}$ & $\begin{array}{l}\text { Good hygienic practices; } \\
\text { prevent infected workers } \\
\text { from preparing food; RTE } \\
\text { foods, eg, hors d'oeuvres } \\
\text { with much handling at } \\
\text { greatest risk; avoid or } \\
\text { thoroughly cook shellfish }\end{array}$ & ELISA, RT-PCR & $\begin{array}{l}\text { Often the infections are } \\
\text { introduced from the community } \\
\text { into various settings, especially } \\
\text { during winter when outbreaks are } \\
\text { common leading to temporary } \\
\text { closures of hospitals and nursing } \\
\text { homes. } \\
\text { In the USA, >60\% of all NoV } \\
\text { outbreaks occur in long-term care } \\
\text { facilities. } \\
\text { This contrasts with the settings } \\
\text { reported in Europe, Japan, and } \\
\text { other high-income settings, where } \\
\text { outbreaks in acute-care hospitals } \\
\text { are common and roughly equal in } \\
\text { number to outbreaks in long-term } \\
\text { care facilities; however, what } \\
\text { proportion of these outbreaks are } \\
\text { foodborne is unknown. } \\
\text { Person-to-person transmission } \\
\text { most frequent but many } \\
\text { foodborne and waterborne } \\
\text { outbreaks reported, mostly } \\
\text { in foodservice settings like } \\
\text { restaurants and large catered } \\
\text { events, and institutional settings, } \\
\text { eg, schools, universities, child care } \\
\text { centers, sporting events, prisons } \\
\text { and troops overseas, banquet halls, } \\
\text { wedding receptions, and family } \\
\text { social events like birthday parties } \\
\text { and potluck meals, where people } \\
\text { eat food prepared by others. } \\
\text { Many outbreaks reported from } \\
\text { oysters harvested from polluted } \\
\text { waters }\end{array}$ & $\begin{array}{l}3,10,14-16, \\
20,22,47 \\
94-99\end{array}$ \\
\hline $\begin{array}{l}\text { Two (6) months. } \\
\text { No specific } \\
\text { antiviral drug } \\
\text { treatment }\end{array}$ & $\begin{array}{l}\text { Peak shedding } 2 \text { weeks } \\
\text { before onset of jaundice, } \\
\text { but HAV can be } \\
\text { excreted up to } 5 \text { months } \\
\text { post infection. } \\
\text { Infections most } \\
\text { likely in winter and } \\
\text { spring months; HAV } \\
\text { is excreted in large } \\
\text { quantities, eg, } 10^{6}-10^{8} \\
\text { per gram, approximately } \\
\text { II days prior to } \\
\text { appearance of symptoms } \\
\text { and } 36 \text { days after } \\
\text { recovery; many virions } \\
\text { excreted in stools of } \\
\text { asymptomatic persons } \\
\text { as well }\end{array}$ & $\begin{array}{l}\text { Hepatitis A can be } \\
\text { prevented by vaccination, } \\
\text { good hygiene and sanitation, } \\
\text { and avoidance of shellfish } \\
\text { from polluted waters; } \\
\text { bacterial indicator testing } \\
\text { of harvest areas and } \\
\text { depuration of shellfish are } \\
\text { of limited value for detected } \\
\text { or removing enteric viruses. } \\
\text { Immunoglobulin given to } \\
\text { contacts of an infected } \\
\text { food worker. Proper hand } \\
\text { hygiene essential; separate } \\
\text { vaccines for children and } \\
\text { adults; lasts } 20 \text { years }\end{array}$ & $\begin{array}{l}\text { Detection of IgM } \\
\text { antibody to capsid } \\
\text { proteins 5-10 days } \\
\text { before onset of } \\
\text { symptoms and } \\
\text { persist for } 6 \text { months } \\
\text { ELISA }\end{array}$ & $\begin{array}{l}\text { RTE foods and bivalve molluscs, } \\
\text { associated with foodborne } \\
\text { disease outbreaks, some large; } \\
\text { strawberries, tomatoes, lettuce, } \\
\text { cole slaw, green onions, sushi, } \\
\text { oysters, crab, grapes, cake, } \\
\text { burritos, deli meat, salsa, French } \\
\text { fries, milkshake, ice, unspecified } \\
\text { sandwiches and salads }\end{array}$ & $\begin{array}{l}2,3,22,29 \\
47,69,95 \\
100-104\end{array}$ \\
\hline
\end{tabular}


Table I (Continued)

\begin{tabular}{|c|c|c|c|}
\hline $\begin{array}{l}\text { Virus, discovery } \\
\text { date, classification }\end{array}$ & $\begin{array}{l}\text { Structure } \\
\text { and size }\end{array}$ & $\begin{array}{l}\text { Transmission and } \\
\text { infective dose }\end{array}$ & Survival \\
\hline & & & $\begin{array}{l}\text { Inactivated by heating to }>85^{\circ} \mathrm{C} \\
\text { for one minute, (however, since it } \\
\text { is more common to heat bivalves } \\
\text { until the shells are opened, which in } \\
\text { clams is obtained at } 70^{\circ} \mathrm{C} \text { after } \\
47 \pm 5 \text { seconds, HAV and other } \\
\text { enteric viruses probably survive); } \\
\text { ultraviolet radiation, formalin, ozone, } \\
\text { iodine, or concentrated chlorine, } \\
\text { and high pressure processing are } \\
\text { effective, but modified atmosphere } \\
\text { packaging does not inhibit HAV; } \\
3 \text { kGy was needed to achieve a I log } \\
\text { reduction of HAV on lettuce and } \\
\text { strawberries; a maximum of I- } 2 \text { log } \\
\text { removal of viruses could be achieved } \\
\text { by washing produce with water. } \\
\text { HAV survives freezing }\end{array}$ \\
\hline
\end{tabular}

HEV, 1983; HEV is the only member of the genus Hepevirus, family Hepeviridae

HEV has four genotypes: genotype I is regularly found in HEV-endemic areas such as Africa and Asia; genotype 2 in Mexico and West Africa; genotype 3 in the USA, Europe, and Japan; and genotype 4 in Asia.

Genotypes I and 2 are mainly transmitted by water, while 3 and 4 are zoonotic genotypes associated with consumption of meat from infected animals
Single-stranded positive-sense RNA genome of $7.2 \mathrm{~kb}$; spherical viral particle $27-30 \mathrm{~nm}$ in size
Fecal-oral from water and food, person-to-person transmission uncommon. Unlike HAV found in domestic and wild animals, eg, pigs, rodents, chickens, dogs, cows, sheep, and goats, HEV has also been identified in pets; exposure of pet owners may account for sporadic cases of HEV infection.

Foodborne transmission of HEV has occurred via ingestion of contaminated deer, boar, and pig meat. Replication of viral particles occurs in intestinal mucosal cells, but starts in the cytoplasm of hepatocytes; virions are transported with bile from liver tissue to the intestines. The highest infection risk is associated with travel to endemic countries, overcrowded refugee camps, people with chronic liver disease, handling non-human primates, pigs, cows, sheep, and goats; likely some animal crossspecies transmission.

The infectious dose is unknown
$\mathrm{HEV}$ is stable in alkaline and acidic environments, when frozen for more than 10 years, and remains infectious at up to $60^{\circ} \mathrm{C}$, suggesting that raw, rare-cooked, or slightly steamed contaminated seafood may transmit HEV to consumers
Incubation period

Hepatis A represe

Hepatitis A represents about one third of all cases of viral hepatitis. Unlike hepatitis B and $C$, hepatitis $A$ infection does not cause chronic liver disease and is rarely fatal, but it can cause debilitating symptoms and fulminant hepatitis (acute liver failure), which is associated with high mortality

2 weeks to 2 months. Influenza-like symptoms, abdominal pain, tenderness, nausea, vomiting, and fever in the first phase of I-10 days. The second phase (15-40 days) with concurrent jaundice, anorexia, hepatomegaly, myalgia, and dark urine is followed by viremia, liver enzyme elevations, antibody seroconversion, and clearing of the virus; typically, disease self-limiting without progression to chronic illness; however, $60 \%$ cases of HEV infection in immunocompromised patients after solid organ transplantation develop chronic hepatitis without antiviral treatment 


\begin{tabular}{|c|c|c|c|c|c|}
\hline $\begin{array}{l}\text { Duration and } \\
\text { therapy }\end{array}$ & Shedding & Prevention and control & $\begin{array}{l}\text { Detection } \\
\text { methods }\end{array}$ & $\begin{array}{l}\text { Outbreaks and food } \\
\text { implicated }\end{array}$ & References \\
\hline & $\begin{array}{l}\text { Risk factors include } \\
\text { travel to endemic areas, } \\
\text { sharing a household } \\
\text { with a 3-10-year-old } \\
\text { child; contact with an } \\
\text { HAV-infected person, } \\
\text { consumption of bivalve } \\
\text { molluscs, and untreated } \\
\text { water }\end{array}$ & $\begin{array}{l}\text { There are two vaccines: } \\
\text { one containing inactivated } \\
\mathrm{HAV} \text {, and another } \\
\text { containing a live but } \\
\text { attenuated virus to protect } \\
\text { against HAV in more than } \\
95 \% \text { of cases for longer than } \\
25 \text { years. IgG administered } \\
\text { intramuscularly is used for } \\
\text { the prevention of HAV } \\
\text { infection. } \\
\text { HAV can be eliminated } \\
\text { on surfaces by using a } \\
\text { solution of I:I00 dilution } \\
\text { of household bleach in } \\
\text { tap water; foods must be } \\
\text { heated to temperatures } \\
>85^{\circ} \mathrm{C} \text { for at least one } \\
\text { minute to inactivate the } \\
\text { virus }\end{array}$ & & & \\
\hline $\begin{array}{l}\text { Higher mortality } \\
\text { in pregnant } \\
\text { women than } \\
\text { healthy non- } \\
\text { pregnant adults }\end{array}$ & $\begin{array}{l}\text { Humans and other } \\
\text { animals excrete a } \\
\text { considerable amount } \\
\text { of virus early in the } \\
\text { acute phase of HEV } \\
\text { infection and contribute } \\
\text { to maintain the cycle of } \\
\text { endemicity }\end{array}$ & $\begin{array}{l}\text { Control of animal waste, } \\
\text { run-off, and decontaminated } \\
\text { sewage limits spread of } \\
\text { HEV to coastal and surface } \\
\text { waters/shellfish. } \\
\text { Vaccine available in the } \\
\text { People's Republic of China }\end{array}$ & $\begin{array}{l}\text { RT-PCR and real- } \\
\text { time RT-PCR; EIA, } \\
\text { no cell culture }\end{array}$ & $\begin{array}{l}\text { Disease typically transmitted } \\
\text { through fecally contaminated } \\
\text { water and foods. } \\
\text { Genotypes I and } 2 \text { are mainly } \\
\text { transmitted by water, while } 3 \\
\text { and } 4 \text { are zoonotic genotypes and } \\
\text { associated with the consumption } \\
\text { of meat from infected animals. } \\
\text { Food animals may contain HEV, } \\
\text { and high risk foods include } \\
\text { undercooked liver or meat from } \\
\text { domestic pigs, wild boars, deer, } \\
\text { and hare; shellfish in polluted } \\
\text { waters }\end{array}$ & $\begin{array}{l}3,36-38 \\
105,106\end{array}$ \\
\hline
\end{tabular}


Table I (Continued)

\begin{tabular}{|c|c|c|c|c|}
\hline $\begin{array}{l}\text { Virus, discovery } \\
\text { date, classification }\end{array}$ & $\begin{array}{l}\text { Structure } \\
\text { and size }\end{array}$ & $\begin{array}{l}\text { Transmission and } \\
\text { infective dose }\end{array}$ & Survival & $\begin{array}{l}\text { Incubation period } \\
\text { and symptoms }\end{array}$ \\
\hline $\begin{array}{l}\text { HRV, I973; in the } \\
\text { family Reoviridae, } \\
\text { seven RV groups } \\
\text { (A-G); } \\
\text { Group A causes most } \\
\text { human disease }\end{array}$ & $\begin{array}{l}\text { Non-enveloped, } \\
\text { double-stranded } \\
\text { RNA surrounded } \\
\text { by a three-layered } \\
\text { icosahedral } \\
\text { protein capsid; } \\
\text { viral particles are } \\
\text { up to } 76.5 \mathrm{~nm} \text { in } \\
\text { diameter }\end{array}$ & $\begin{array}{l}\text { Fecal-oral, possible aerosol; } \\
\mathrm{I}-10(100) \text { virions needed to } \\
\text { infect enterocytes of small } \\
\text { intestine }\end{array}$ & $\begin{array}{l}\text { Lasts many weeks in the } \\
\text { environment; HRV reduced by } \\
\text { I log on blueberries and basil after } \\
2 \text { days in frozen storage; HRV } \\
\text { inactivated at a } \mathrm{pH} \text { of } 2 \text { at } 37^{\circ} \mathrm{C} \\
\text { with a half-life of less than one } \\
\text { minute, but not in fruit juice } \\
\text { ( } \mathrm{pH} 3.0 \mathrm{I} \text { ) stored at } 4^{\circ} \mathrm{C} \text { for } 3 \text { days } \\
\mathrm{HRV} \mathrm{SA}-\mathrm{I} \text { I survived on lettuce, } \\
\text { radishes, and carrots for up to } \\
30,30 \text {, and } 25 \text { days, respectively, } \\
\text { at refrigeration temperature after } \\
\text { direct inoculation; however, at } \\
\text { room temperature, the survival } \\
\text { periods were } 25,4 \text {, and I } 5 \text { days, } \\
\text { respectively. }\end{array}$ & $\begin{array}{l}2(\mathrm{I}-4) \text { days; HRV } \\
\text { infection characterized } \\
\text { by abrupt onset of fever } \\
\text { and vomiting followed by } \\
\text { watery diarrhea, abdominal } \\
\text { cramps, dehydration; more } \\
\text { severe for malnourished } \\
\text { and immunocompromised; } \\
\text { neonatal infections are } \\
\text { often asymptomatic, but } \\
\text { infant deaths occur, mainly } \\
\text { in developing countries; } \\
\text { less severe for adults and } \\
\text { subsequent infections }\end{array}$ \\
\hline $\begin{array}{l}\text { HAstV, I975; genus } \\
\text { Astrovirus, family } \\
\text { Astroviridae; seven } \\
\text { established genotypes, } \\
\text { correspond with seven } \\
\text { serotypes }\end{array}$ & $\begin{array}{l}\text { Non-enveloped, } \\
\text { single-stranded, } \\
\text { positive-sense } \\
\text { RNA which } \\
\text { contains three } \\
\text { open reading } \\
\text { frames; spherical, } \\
\text { capsid of about } \\
35 \text { nm with } \\
\text { icosahedral } \\
\text { protein }\end{array}$ & $\begin{array}{l}\text { HAstV, can infect the } \\
\text { epithelium of the duodenum; } \\
\text { although initially detected in } \\
\text { children's stool, HAstV have } \\
\text { been found in the feces of a } \\
\text { wide variety of animals, eg, } \\
\text { cats, dogs, cattle, deer, pigs, } \\
\text { sheep, bats, rats, and poultry }\end{array}$ & $\begin{array}{l}\text { At } 4^{\circ} \mathrm{C} \text {, HAstV persists for } 60 \text { days } \\
\text { desiccated on china and } 90 \text { days } \\
\text { on paper, shorter time at higher } \\
\text { temperatures; survives in fresh } \\
\text { water and seawater for many days, } \\
\text { but chlorination reduces viability }\end{array}$ & $\begin{array}{l}\text { 3-5 days. } \\
\text { Vomiting (not as much } \\
\text { as with HRV or NoV), } \\
\text { abdominal cramps, watery } \\
\text { diarrhea, headache, } \\
\text { fever, malaise, anorexia; } \\
\text { asymptomatic infections } \\
\text { occur in children and } \\
\text { adults; hospitalization } \\
\text { rare; serological studies } \\
\text { indicate that most children } \\
\text { are infected with HAstV } \\
\text { and develop antibodies } \\
\text { to the virus early in } \\
\text { life, perhaps protecting } \\
\text { against later infections; } \\
\text { immunocompromised and } \\
\text { elderly are at high risk for } \\
\text { infections }\end{array}$ \\
\hline $\begin{array}{l}\text { SaV, I976; genus } \\
\text { Sapovirus, family } \\
\text { Caliciviridae; SaV are } \\
\text { divided into seven } \\
\text { genogroups, four of } \\
\text { which (genogroups I, } \\
\text { II, IV, and V) contain } \\
\text { viruses that infect } \\
\text { humans, while GIII, } \\
\text { GVI, and GVII infect } \\
\text { porcines }\end{array}$ & $\begin{array}{l}\text { Non-enveloped, } \\
\text { small single- } \\
\text { stranded } \\
\text { positive-sense } \\
\text { RNA viruses, } \\
\text { genome contains } \\
\text { two major open } \\
\text { reading frames, } \\
30-38 \text { nm in } \\
\text { diameter }\end{array}$ & $\begin{array}{l}\text { Fecal-oral route. } \\
\text { SaV can be transmitted } \\
\text { from person to person via } \\
\text { contact with SaV-positive } \\
\text { feces, vomitus, or SaV- } \\
\text { contaminated materials/ } \\
\text { surfaces or via contaminated } \\
\text { food and drinking water; } \\
\text { SaV may enter the food } \\
\text { supply at any point along the } \\
\text { farm-to-fork continuum, eg, } \\
\text { sewage-contaminated waters } \\
\text { used for growing or irrigating } \\
\text { products consumed raw, such } \\
\text { as shellfish and fresh produce; } \\
\text { although, like other enteric } \\
\text { viruses, most foods are } \\
\text { thought to be contaminated } \\
\text { by an infected food handler. } \\
\text { Likely a low infectious dose } \\
\text { similar to that of NoV }\end{array}$ & $\begin{array}{l}\text { Porcine } \mathrm{SaV} \text { is stable at } \mathrm{pH} 3.0-8.0 \\
\text { at room temperature for one hour, } \\
\text { sensitive to ethanol treatment } \\
(60 \% \text { and } 70 \%) \text { at room temperature } \\
\text { for } 30 \text { seconds, inactivated by } \\
200 \mathrm{mg} / \mathrm{L} \text { sodium hypochlorite at } \\
\text { room temperature for } 30 \text { minutes, } \\
\text { inactivated by heating at } 56^{\circ} \mathrm{C} \text { for } \\
2 \text { hours, but survives on lettuce for } \\
\text { a week at } 4^{\circ} \mathrm{C}\end{array}$ & $\begin{array}{l}0.5-2 \text { days. } \\
\text { Diarrhea and vomiting often } \\
\text { accompanied with fever, } \\
\text { nausea, and abdominal } \\
\text { cramps }\end{array}$ \\
\hline
\end{tabular}




\begin{tabular}{|c|c|c|c|c|}
\hline $\begin{array}{l}\text { Duration and } \\
\text { therapy }\end{array}$ & Shedding & Prevention and control & $\begin{array}{l}\text { Detection } \\
\text { methods }\end{array}$ & $\begin{array}{l}\text { Outbreaks and food } \\
\text { implicated }\end{array}$ \\
\hline $\begin{array}{l}\text { 3-8 (up to 22) } \\
\text { days; self-limiting, } \\
\text { therapy focused } \\
\text { on replacement } \\
\text { of fluids and } \\
\text { electrolytes, } \\
\text { given that no } \\
\text { antiviral agents } \\
\text { are currently } \\
\text { available. } \\
\text { Probiotics } \\
\text { decrease } \\
\text { diarrheal duration }\end{array}$ & $\begin{array}{l}10^{\prime \prime} \text { particles/stool. } \\
\text { Virus typically shed in } \\
\text { feces for } 4 \text { days although } \\
\text { excretion for }>30 \text { days } \\
\text { has been reported in } \\
\text { immunocompromised } \\
\text { patients }\end{array}$ & $\begin{array}{l}\text { Good hygiene not enough; } \\
\text { Oral vaccine for infants }\end{array}$ & $\begin{array}{l}\text { ELISA, RT-PCR, } \\
\text { rarely cell culture }\end{array}$ & $\begin{array}{l}\text { Outbreaks of HRV Group A } \\
\text { diarrhea are common among } \\
\text { hospitalized infants, young } \\
\text { children in child care centers, and } \\
\text { elderly people in nursing homes; } \\
\text { foodborne and waterborne } \\
\text { outbreaks rare: RTE food } \\
\text { contaminated by food preparers: } \\
\text { sandwiches (chicken, tuna, turkey), } \\
\text { salads (chicken, tuna), conch, deli } \\
\text { meat, multiple foods }\end{array}$ \\
\hline $\begin{array}{l}2-3(9) \text { days; } \\
\text { recurrence } \\
\text { possible } \\
7-10 \text { days later }\end{array}$ & $\begin{array}{l}\text { Volunteer studies } \\
\text { showed that many } \\
\text { are asymptomatic but } \\
\text { with diarrhea profuse } \\
\text { shedding of HAstV can } \\
\text { occur }\end{array}$ & $\begin{array}{l}\text { Hands, fomites, and } \\
\text { contaminated water are } \\
\text { among the principal vehicles } \\
\text { for the transmission of } \\
\text { enteric viral diseases } \\
\text { and this would apply to } \\
\text { HAstV; good hand hygiene, } \\
\text { decontamination of food } \\
\text { contact surfaces, and } \\
\text { avoidance of shellfish from } \\
\text { polluted waters reduce the } \\
\text { risk of HAstV foodborne } \\
\text { and waterborne infections }\end{array}$ & $\begin{array}{l}\text { RT-PCR. ELISA, cell } \\
\text { culture, eg, Vero } \\
\text { cells }\end{array}$ & $\begin{array}{l}\text { Common source and person-to- } \\
\text { person transmission. } \\
\text { Fecally contaminated fomites } \\
\text { have been implicated in outbreaks } \\
\text { in institutions, eg, child care } \\
\text { centers, hospitals, nurseries, } \\
\text { schools and military facilities; } \\
\text { foodborne infections rare, fecally } \\
\text { contaminated salad items; indirect } \\
\text { evidence of HAstV causing } \\
\text { waterborne gastroenteritis }\end{array}$ \\
\hline $\begin{array}{l}\text { 2-6 days. } \\
\text { Self-limiting; } \\
\text { therapy for } \\
\text { dehydration } \\
\text { and electrolyte } \\
\text { imbalances; no } \\
\text { vaccines }\end{array}$ & $\begin{array}{l}10^{5}-10^{11} \text { viral copies per } \\
\text { gram stool. } \\
\text { Virus typically shed in } \\
\text { stool for up to } 2 \text { weeks } \\
\text { after illness onset, } \\
\text { although some infected } \\
\text { individuals may shed } \\
\text { high volumes of virus } \\
\text { ( } \geq 10^{5} \text { viral copies per } \\
\text { gram stool for as long as } \\
4 \text { weeks) }\end{array}$ & $\begin{array}{l}\text { Shellfish should be } \\
\text { adequately cooked and } \\
\text { fresh produce washed } \\
\text { thoroughly before } \\
\text { consumption, proper hand } \\
\text { hygiene, and disinfect } \\
\text { potentially contaminated } \\
\text { environmental surfaces with } \\
\text { a chlorine bleach solution } \\
\text { with a concentration of } \\
\text { I,000-5,000 ppm for other } \\
\text { approved disinfectants }\end{array}$ & RT-PCR, ELISA & $\begin{array}{l}\text { SaV outbreaks occur throughout } \\
\text { the year in all age groups in } \\
\text { various settings, such as child care } \\
\text { centers, kindergartens, schools, } \\
\text { colleges, hospitals, nursing homes, } \\
\text { restaurants, hotels, wedding halls, } \\
\text { and ships; occasional foodborne } \\
\text { outbreaks; boxed lunches, meat } \\
\text { balls, ham; SaV at } 10^{4} \text { copies per } \\
\text { gram of digestive tissue in oysters, } \\
\text { cockles, clams; up to } 10^{5} \text { copies } \\
\text { per liter in wastewater treatment } \\
\text { plant influent; } 10^{9} \text { copies per liter } \\
\text { in untreated wastewater }\end{array}$ \\
\hline
\end{tabular}

References

$22,43,47$,

$69,107-110$ hospitalized infants, young elderly people in nursing homes; odborne and waterborne contaminated by food preparers: sandwiches (chicken, tuna, turkey), ads (chicken, tuna), conch, de available. decrease diarrheal duration

contaminated water are the principal vehicles culture, eg, Vero

45,47,69,

III,II2 
Table I (Continued)

\begin{tabular}{|c|c|c|c|c|}
\hline $\begin{array}{l}\text { Virus, discovery } \\
\text { date, classification }\end{array}$ & $\begin{array}{l}\text { Structure } \\
\text { and size }\end{array}$ & $\begin{array}{l}\text { Transmission and infective } \\
\text { dose }\end{array}$ & Survival & $\begin{array}{l}\text { Incubation period } \\
\text { and symptoms }\end{array}$ \\
\hline $\begin{array}{l}\text { AiV, 1989; genus } \\
\text { Kobuvirus, family } \\
\text { Picornaviridae }\end{array}$ & $\begin{array}{l}\text { Single-stranded } \\
\text { positive-sense } \\
\text { RNA molecule } \\
\text { with } 8,25 \text { I bases } \\
\text { excluding a } \\
\text { poly(A) tail; it } \\
\text { contains a large } \\
\text { open reading } \\
\text { frame with 7,302 } \\
\text { nucleotides; } \\
\text { similar structure } \\
\text { to HAstV }\end{array}$ & $\begin{array}{l}\text { Fecal-oral route. } \\
\text { Attachment of the virus to } \\
\text { host receptors mediates } \\
\text { endocytosis of the virus into } \\
\text { the host cell; the capsid then } \\
\text { undergoes a conformational } \\
\text { change and possibly opens a } \\
\text { pore in the host endosomal } \\
\text { membrane and the viral } \\
\text { genomic RNA penetrates into } \\
\text { the host cell cytoplasm }\end{array}$ & $\begin{array}{l}\text { Survives in the environment but } \\
\text { inactivated by ultraviolet light; may } \\
\text { survive high pressure processing at } \\
600 \mathrm{MPa} \text { for } 5 \text { minutes }\end{array}$ & $\begin{array}{l}0.5-2.5 \text { days. } \\
\text { Diarrhea, vomiting and } \\
\text { abdominal cramps; children } \\
\text { may be hospitalized }\end{array}$ \\
\hline $\begin{array}{l}\text { MERS-CoV, 20I2; } \\
\text { Arabian Peninsula, } \\
\text { lineage C of } \\
\text { Betacoronavirus, family } \\
\text { Coronavirinae }\end{array}$ & $\begin{array}{l}\text { Enveloped virus } \\
\text { with a positive } \\
\text { sense single- } \\
\text { stranded RNA } \\
\text { genome and a } \\
\text { nucleocapsid of } \\
\text { helical symmetry; } \\
\text { genome contains } \\
30 \text { kb nucleotides } \\
\text { and I0+ plus open } \\
\text { reading frames }\end{array}$ & $\begin{array}{l}\text { Aerosols most frequently, but } \\
\text { possibly through consumption } \\
\text { of dromedary camel products }\end{array}$ & $\begin{array}{l}\text { Coronoviruses are stable in feces } \\
\text { and urine at room temperature } \\
\text { for at least I-2 days; heat and } \\
\text { disinfectants destroy them }\end{array}$ & $\begin{array}{l}2-14 \text { days. } \\
\text { Fever, cough, shortness } \\
\text { of breath, evidence of } \\
\text { pulmonary parenchymal } \\
\text { disease (eg, pneumonia or } \\
\text { acute respiratory distress } \\
\text { syndrome); mortality rate } \\
\text { of } 30 \%\end{array}$ \\
\hline $\begin{array}{l}\text { HAdV, I953; } \\
\text { genus Mastadenovirus, } \\
\text { family Adenoviridae; } \\
\text { 5I HAdV serotypes, } \\
\text { further subdivided } \\
\text { into six species or } \\
\text { subgroups A-F; } \\
\text { subgroup F HAstV } \\
\text { types } 40 \text { and } 4 \text { I } \\
\text { responsible for } \\
\text { gastroenteritis; there } \\
\text { are also non-human } \\
\text { AdV }\end{array}$ & $\begin{array}{l}\text { Non-enveloped } \\
\text { viruses with } \\
\text { a diameter of } \\
70-100 \mathrm{~nm} \text {, } \\
\text { double-stranded, } \\
\text { linear DNA } \\
\text { displaying genome } \\
\text { sizes of 34-37 kb } \\
\text { surrounded by } \\
\text { a icosahedron } \\
\text { with fiber-like } \\
\text { projections }\end{array}$ & $\begin{array}{l}\text { Aerosol into either the } \\
\text { respiratory or gastrointestinal } \\
\text { tracts (infects the mucosa } \\
\text { of the duodenum), the } \\
\text { oropharynx or conjunctiva; } \\
\text { fecal-oral spread, including } \\
\text { contact with recreational } \\
\text { freshwater or tap water, } \\
\text { infected tissue, airflow filters, } \\
\text { fomites, or environmental } \\
\text { surfaces; decontamination } \\
\text { with } 85 \%-95 \% \text { ethanol for at } \\
\text { least } 2 \text { minutes or with } \mathrm{NaOH} \\
\text { for } 10 \text { minutes }\end{array}$ & $\begin{array}{l}\text { Stable after several weeks in } \\
\text { moisture-free environments, and } \\
\text { resistant to many disinfectants }\end{array}$ & $\begin{array}{l}\text { 5-9 (2-14) days; acute } \\
\text { febrile respiratory disease, } \\
\text { gastroenteritis, infantile } \\
\text { diarrhea, hepatitis, } \\
\text { keratoconjunctivitis, } \\
\text { meningoencephalitis, } \\
\text { cystitis, upper and } \\
\text { lower respiratory tract } \\
\text { infections, and myocarditis; } \\
\text { immunocompromised at } \\
\text { greater risk from serious } \\
\text { illness }\end{array}$ \\
\hline $\begin{array}{l}\text { Enteroviruses, most } \\
\text { known for many } \\
\text { years. RNA viruses } \\
\text { of the Picornaviridae } \\
\text { family, are ubiquitous } \\
\text { pathogens which } \\
\text { include more than } 70 \\
\text { different serotypes } \\
\text { of polioviruses, } \\
\text { Coxsackievirus group } \\
\text { A and group B viruses, } \\
\text { and echoviruses group; } \\
\text { poliovirus is the virus } \\
\text { on main concern but } \\
\text { is almost eradicated } \\
\text { today }\end{array}$ & $\begin{array}{l}\text { Morphologically all } \\
\text { enteroviruses are } \\
\text { alike: small, ether } \\
\text { insensitive viruses, } \\
\text { single-stranded } \\
\text { RNA genome, and } \\
\text { the nucleocapsid } \\
\text { has an icosahedral } \\
\text { symmetry, and is } \\
\text { naked }\end{array}$ & $\begin{array}{l}\text { Humans are the only known } \\
\text { natural hosts and fecal-oral } \\
\text { is the most common route of } \\
\text { transmission; viruses replicate } \\
\text { in the lymph nodes of the } \\
\text { respiratory or gastrointestinal } \\
\text { system; an initial minor } \\
\text { viremia results in spread to } \\
\text { secondary sites, eg, heart, } \\
\text { liver, and skin, central nervous } \\
\text { system; as antibodies develop, } \\
\text { viremia ends and the clinical } \\
\text { recovery begins }\end{array}$ & $\begin{array}{l}\text { Poliovirus, echovirus, and } \\
\text { Coxsackievirus remained infectious } \\
\text { for } 2 \text { to }>12 \text { days on painted } \\
\text { wood, glass, and cotton fabric, with } \\
\text { greater survival being observed if the } \\
\text { inoculum also contained coliform } \\
\text { bacteria, protein, fat, and dust } \\
\text { particles; enteroviruses can survive } \\
\text { in soil, sludge, vegetables, and } \\
\text { freshwater sources for prolonged } \\
\text { periods of time; poliovirus titer } \\
\text { was reduced by } 3 \text { log after } 28 \text { days } \\
\text { in seawater; } 0-1 \text { log decline on } \\
\text { lettuce, green onions, white cabbage, } \\
\text { strawberries and raspberries at } 4{ }^{\circ} \mathrm{C} \\
\text { over I } 5 \text { days; polio survived in crabs } \\
\text { and oysters for many days }\end{array}$ & $\begin{array}{l}\text { Fever, vomiting, diarrhea, } \\
\text { and malaise; manifestations } \\
\text { associated with specific viral } \\
\text { agents include hemorrhagic } \\
\text { conjunctivitis, pharyngitis, } \\
\text { pleurodynia, herpangina, } \\
\text { hand-foot-and-mouth } \\
\text { disease, paralysis, hepatitis, } \\
\text { myocarditis, pericarditis, } \\
\text { encephalitis, aseptic } \\
\text { meningitis, and multi-organ } \\
\text { failure }\end{array}$ \\
\hline
\end{tabular}

Abbreviations: NoV, norovirus; Ig, immunoglobulin; FCV, feline calcicivirus; RTE, ready-to-eat; HRV, human rotavirus; ELISA, enzyme-linked immunosorbent assay; AiV, Aichi virus; SaV, sapovirus; EIA, enzyme-linked immunosorbent assay; HAdV, human adenovirus; HAstV, human astrovirus; HAV, hepatitis A virus; HEV, hepatitis E virus; MERS-CoV, Middle East respiratory syndrome coronavirus; RT-PCR; reverse transcriptase polymerase chain reaction; RQ-PCR, real time quantitative polymerase chain reaction. 


\begin{tabular}{lllll}
\hline $\begin{array}{l}\text { Duration and } \\
\text { therapy }\end{array}$ & Shedding & Prevention and control & $\begin{array}{l}\text { Detection } \\
\text { methods }\end{array}$ & $\begin{array}{l}\text { Outbreaks and food } \\
\text { implicated }\end{array}$ \\
\hline $\begin{array}{l}\text { Duration } \\
\text { unknown but }\end{array}$ & $\begin{array}{l}10^{2}-10^{12} \text { RNA copies } \\
\text { per gram stool }\end{array}$ & $\begin{array}{l}\text { Presumably good hygiene } \\
\text { and avoiding uncooked } \\
\text { oysters }\end{array}$ & $\begin{array}{l}\text { RT-PCR, cell culture } \\
\text { in Vero cells }\end{array}$ & $\begin{array}{l}\text { Widespread in environment, } \\
\text { particularly wastewaters; }\end{array}$ \\
$\begin{array}{l}\text { longer than one } \\
\text { day; self-limiting }\end{array}$ & & & & $\begin{array}{l}\text { outbreaks from oysters in Japan, } \\
\text { and France; outbreak of unknown } \\
\text { origin occurred in Germany }\end{array}$
\end{tabular}

Anti-viral drugs Patients can shed the have some effect virus after resolution of symptoms, but the duration of infectivity is unknown.

Patients are not contagious during the incubation period; asymptomatic cases might not be contagious

I-2 weeks; usually selflimiting but antiretroviral therapy can be used

From $<10^{6}$ virus copies per gram stool (low risk of adenoviremia) to $10^{6}-10^{11}$ virus copies per gram (high risk of viremia and disseminated disease); $10^{2}-10^{4}$ viral copies per $\mathrm{mL}$ blood
General hygiene, face masks when working with camels; cooking or avoiding consuming camel products. No vaccines

Chlorinate swimming pools; good hygiene practices; live oral vaccine against two types
RT-PCR, RQ-PCR, immunofluorescence staining for antigen detection and viral culture, eg, human lung
RT-PCR of sputum, feces, and urine

Camels and camel products, eg, milk and possibly meat; limited person-to-person transmission
$61,115,65$

Child care centers and in households with young children (infantile diarrhea), summer camps, schools, swimming pools, armed forces bases, nosocomial transmission, occasionally foods: ice, sausage
Antiviral drug treatments;

intravenous immunoglobulin may be of benefit for immunodeficient patients with persistent enterovirus infection
Up to 60 days in stool

Avoidance of drinking polluted water. Oral poliovirus vaccine
Viral culture, PCR, and serologic diagnosis
Hand, foot, and mouth disease, conjunctivitis, respiratory illness (Coxsackievirus and enterovirus), viral meningitis (echoviruses); historic waterborne outbreaks from polio virus 
contaminated mussels, while HAdV and poliovirus were reduced by at least $3 \log { }^{22}$ Because shellfish can be held in depuration tanks for only a relatively short period, relaying in pristine waters for weeks could be a good alternative for heavily polluted shellfish..$^{22,30}$

\section{Outbreak examples}

\section{Clams}

The largest viral foodborne disease outbreak ever documented occurred in Shanghai, People's Republic of China, in 1988, with almost 300,000 cases associated with consumption of clams harvested from newly discovered clam beds in sewage-polluted waters. ${ }^{31} \mathrm{~A}$ risk assessment applied to two HAV outbreaks in Valencia, Spain, associated with frozen coquina clams imported from Peru in 1999 (184 cases) and 2008 (100 cases) showed the likelihood of infection. ${ }^{32}$ Both outbreaks lasted several months, with clams from different shipments being consumed. These bivalve molluscs complied with European Union standards, based on the numbers of Escherichia coli in shellfish meat, but E. coli is not necessarily a reliable indication of enteric viruses in molluscan shellfish or their waters. Very similar HAV sequences were detected in clinical and bivalve samples from both outbreaks. The authors estimated that from the 1999 outbreak, there were 1-10 infectious units per gram after light cooking of clams with attack rates of $0.12-0.57$, assuming a single serving of $60 \mathrm{~g}$ of shellfish. A risk assessment showed that, as to be expected, the attack rates decreased the more the clams were cooked, eg, for the $1.2 \times 10^{5}$ genome copies in a May 2008 shipment these were 0.91 (raw), 0.43 (lightly cooked), and 0.21 (well cooked). Based on national epidemic data, HAV cases were also likely associated with these clams in Peru.

\section{Green onions}

The most widespread HAV outbreak in the USA affected at least 640 people with four deaths in north-eastern Ohio and south-western Pennsylvania in late 2003 arising from green onions served in salsa at a restaurant in Monaca, Pennsylvania; the onions were likely contaminated at source in Mexico. ${ }^{33}$

\section{Semidried tomatoes}

In 2010, 59 cases of non-travel-associated illness with genotype I, subtype B (IB) strains of HAV in France were linked with most cases consuming semidried tomatoes from one of three different sandwich shop chains, traced back to a supplier in France that imported frozen semid- ried tomatoes from Turkey. ${ }^{34}$ Three other HAV outbreaks caused by highly similar IB strains were associated with eating semidried tomatoes in Australia in 2009 and in the Netherlands in 2010. The investigation showed that a foreign supplier was likely, and that the diffuse pattern of distribution of cases pointed to a contamination source further back in the food production chain; contaminated water could have been used during cultivation of the tomatoes, as described for a green onion outbreak. ${ }^{33}$ It is possible then that all four outbreaks could have originated from a Turkish farm operation.

\section{Pomegranate arils}

An outbreak of HAV genotype I subtype B infection in 165 individuals occurred in ten US states in 2013 associated with pomegranate arils imported from Turkey where this genotype is common. ${ }^{35}$ Sixty-nine individuals were hospitalized, two had fulminant hepatitis, and one required a liver transplant.

\section{Frozen berries}

In June 2013, frozen berry mix containing fruit from the USA, Argentina, Chile, and Turkey purchased by approximately 240,000 people in the USA was subject to recall after at least 158 people were infected with HAV, 69 of whom were hospitalized; ${ }^{2}$ the isolated HAV strain is known to circulate in North Africa and the Middle East but rarely in the USA.

\section{Hepatitis E virus}

The World Health Organization reports over 20 million HEV infections annually with 56,600 related deaths, mainly associated with contaminated water, with the highest prevalence in East and South Asia. ${ }^{28,36}$ In industrialized regions, although the incidence of clinical HEV in humans is low, the seroprevalence of antibodies against HEV is relatively high, indicating a high proportion of subclinical disease and/or underdiagnoses ${ }^{37}$ Although some exposure may arise from travel to endemic regions, HEV can be acquired domestically. Detection of HEV in pork liver sold in retail locations has been reported in Japan, the USA, and the Netherlands. ${ }^{37}$ Foodborne HEV outbreaks have been reported, usually from the consumption of raw or undercooked meat. Locally acquired HEV infections have increased in the UK since 2010. A case-control study investigated the association between consumption of pork products, eg, pies, ham, and sausages, and HEV infection; cooking practices for processed pork may be inadequate, eg, $<70^{\circ} \mathrm{C}$ for 20 minutes to prevent HEV transmission. ${ }^{38}$ The following outbreaks 
demonstrate how HEV is transmitted through a variety of contaminated foods.

\section{Outbreak examples \\ Sausage}

In 2007, in Corsica, France, seven of 13 individuals who ate raw figatellu, a traditional sausage made with pig liver and commonly eaten raw, were identified with acute or recent HEV infection. Genotype $3 \mathrm{HEV}$ sequences were recovered from seven sausages purchased from supermarkets in southeastern France and were genetically linked with patients who ate raw figatellu. ${ }^{39}$

\section{Venison}

An HEV outbreak was reported from Japan in 2003 associated with consumption of undercooked deer meat 6-7 weeks before symptom onset. The HEV nucleotide sequences in the remaining meat matched those from patients and also wild boar meat in a separate study. Family members who did not eat the meat, or ate very little, did not become infected..$^{40,41}$

\section{Shellfish}

Four vacationers reported acute $\mathrm{HEV}$ infection upon returning from a world cruise to the UK in 2008. Investigation revealed 195 of 789 persons were seropositive for HEV and 33 had immunoglobulin $\mathrm{M}$ levels, indicating recent acute infection (eleven were symptomatic). Analysis showed significant association between acute $\mathrm{HEV}$ infection and being male, drinking alcohol, and consuming shellfish while on board, demonstrating this was likely a common source foodborne outbreak. ${ }^{42}$ The type of shellfish could not be specified, but could have arisen from European shipments contaminated by polluted waters and brought aboard at Southampton.

\section{Rotavirus}

HRV is among the leading causes of diarrhea and dehydration in children worldwide, particularly group A. ${ }^{3}$ Group B rotavirus, also known as adult diarrhea rotavirus has caused major epidemics of severe diarrhea affecting thousands of persons of all ages in the People's Republic of China. Group C rotavirus has been associated with rare and sporadic cases of diarrhea in children in many countries; however, the first outbreaks were reported in Japan and England. In the USA, the occurrence of rotavirus disease has dropped considerably since introduction of a vaccine in $2006 .{ }^{3}$ It is difficult to distinguish illness caused by HRV or other enteric viruses, although HRV may cause more severe diarrhea and is more frequently associated with fever and vomiting than acute diarrhea caused by other agents. HRV can spread rapidly in child care centers, where children may be asymptomatic. Rotaviruses are rapidly inactivated at a $\mathrm{pH}$ of 2 at $37^{\circ} \mathrm{C}$, with half-lives of less than one minute. These acidic conditions represent the environment encountered in the stomach; this could account for the fact that HRV disease occurs in children younger than 3 years as the stomach in this age group is characterized by a higher $\mathrm{pH} .{ }^{22}$ The Centers for Disease Control and Prevention reports over 3 million cases of HRV illness annually in the USA, with an estimate of 15,433 cases that are identified as foodborne. ${ }^{43}$

\section{Outbreak example: campus sandwiches}

A HRV outbreak occurred on a Washington DC university campus in 2000, with 108 cases associated with eating tuna or chicken salad sandwiches from a campus dining hall. The investigation reported that $40 / 44$ case patients and $27 / 40$ controls consumed at least one deli sandwich from the dining hall during the outbreak period. It was also noted that six employees reported illness. Group A HRV was recovered from 9/27 stool specimens. The outbreak began as foodborne, but spread by person-to-person contact during the second week. $^{44}$

\section{Human astrovirus}

HAstVs are widespread globally. ${ }^{45}$ Several large foodborne HAstV outbreaks have been reported. ${ }^{46,47}$ Similar to NoV, foods may become contaminated with HAstV at the preharvest stage, as with bivalve molluscs grown in polluted waters or fresh produce, eg, lettuce, green onions, raspberries, and strawberries irrigated with contaminated water. These products usually undergo little if any processing before consumption and act as vehicles for human enteric virus transmission. Serving and chopping utensils or other food contact surfaces play an important role in the institutional spread of HAstV infections, as these viruses can persist on surfaces in high numbers. HAstV is stable in drinking water, fresh surface water, and seawater, indicating another means of transmission. This is demonstrated by an outbreak of gastroenteritis among children and adults who bathed in a Helsinki outdoor wading pool contaminated with $\mathrm{NoV}$ and HAstV. ${ }^{48}$ Kobuvirus, $\mathrm{SaV}$, and HAstV were detected in stools of cases and food handlers (six, three, and one, respectively) during eleven oyster-related outbreaks between 2002 and 2006 in Japan. ${ }^{49}$ In a more recent study, 286 fecal specimens from 88 oyster-associated gastroenteritis outbreaks were examined for the presence of ten human enteric viruses using antigenic or genetic detection methods to determine the prevalence of 
these infections. ${ }^{50}$ Most were caused by NoV, but in five of these outbreaks, HAstV was the major pathogen. For all these outbreaks, the authors hypothesized that the enteric viruses could have been circulating within a given population and been transmitted through the oysters. The following outbreak gives details of one of the earlier HAstV outbreaks.

\section{Outbreak example: school lunches}

HAstV can be an important agent of epidemic acute nonbacterial gastroenteritis in school-aged children and adults in Japan. HAstV was first detected in 1978 among children and staff during an outbreak of gastroenteritis at a Sendai kindergarten. In June 1991, a large outbreak of acute nonbacterial gastroenteritis occurred among students and teachers at ten primary and four junior high schools in Katano City, Osaka, Japan. ${ }^{51}$ The outbreak affected more than 4,700 people, lasted 5 days, and was believed to be associated with contaminated food from a common supplier. The 14 school cafeterias had separate water supplies, but received lunches from a common supplier delivering the food prepared in three central kitchens.

\section{Sapovirus}

$\mathrm{SaV}$ is an important pathogen causing acute gastroenteritis in humans globally, especially in infants and young children; $\mathrm{SaV}$ outbreaks have become more frequent recently, especially in Japan. ${ }^{52,53}$ Although these examples are Japanese, the causative strains have global links, indicating $\mathrm{SaV}$ are widespread and surveillance may not identify these viruses as agents causing outbreaks elsewhere.

\section{Outbreak example: box lunches}

In January 2010, the largest Japanese foodborne outbreak of $\mathrm{SaV}$ occurred in the Aichi, Gifu, and Mie Prefectures. Illness was strongly associated with eating a delivered box lunch prepared by one catering company in Aichi Prefecture. Gastrointestinal symptoms were reported by $655 / 3,827$ (17.1\%) individuals. ${ }^{54}$ Symptoms included diarrhea (92.8\%), abdominal pain $(62.7 \%)$, nausea $(59.8 \%)$, chills $(39.2 \%)$, vomiting (37.1\%), malaise (35.4\%), fever $(32.5 \%)$, and headache $(20.2 \%)$. Of the 655 cases, 350 (53.4\%) developed gastrointestinal symptoms 24-48 hours after eating the lunch. $\mathrm{SaV}$ genotype I.2 was detected in seven of nine people who became ill and in seven of 52 catering company food workers; all were negative for NoV and enteropathogenic bacteria. These $\mathrm{SaV}$ outbreak strains showed $99.5 \%$ nucleotide sequences identical to the strain detected in two simultaneous gastroenteritis outbreaks in school children in Hokkaido, Japan. SaV GI.2 has been frequently detected from outbreak cases in Taiwan, the Netherlands, Sweden, Slovenia, and Hungary during 2007-2009. This suggests worldwide circulation of SaV GI.2, although its main source remains unclear.

\section{Aichi viruses}

Aichi viruses (AiV) have been proposed as causative agents of human gastroenteritis potentially transmitted by fecal-oral routes through contaminated food or water. ${ }^{55} \mathrm{AiV}$ was first isolated in 1989 in Japan from stool specimens collected from 12 of 15 subjects in three outbreaks of oyster-associated nonbacterial acute gastroenteritis in Aichi Prefecture. ${ }^{56}$ The authors conceded that shellfish may be contaminated by several types of prevalent human enteric viruses, and whether or not the $\mathrm{AiV}$ isolates were significant etiologic agents of gastroenteritis remained to be clearly established. However, AiV was subsequently detected in feces of patients with gastroenteritis worldwide. For instance, AiV was isolated in Vero cells from six $(12.3 \%)$ of 47 patients in five gastroenteritis outbreaks, five $(0.7 \%)$ of 722 Japanese travelers returning from tours to Southeast Asian countries and complaining of gastrointestinal symptoms at the quarantine station of Nagoya International Airport in Japan, and five $(2.3 \%)$ of 222 Pakistani children with gastroenteritis. ${ }^{57}$ Several AiV studies demonstrated a high prevalence of AiV antibodies in adults (80\%-99\%), indicating widespread exposure to $\mathrm{AiV}$, but a low incidence of $\mathrm{AiV}$ infection in patients with either sporadic or epidemic gastroenteritis. AiV is frequently found in wastewater and river water. ${ }^{58}$

\section{Outbreak example: shellfish}

Following a flooding event close to a shellfish production lagoon, 205 cases of gastroenteritis were linked to oyster consumption. ${ }^{59}$ Analysis of stool samples collected from 12 individuals showed eight were positive for multiple enteric viruses; one had seven different enteric viruses. Analysis of shellfish implicated in the outbreak demonstrated the same diversity of enteric viruses, with some viral genomic sequences identical to case samples. Shellfish were contaminated by as many as five different enteric viruses; this was the first time AiV was identified in European oysters. Over 3 weeks following the outbreak, there was a progressive reduction in virus contamination in shellfish samples; although the actual etiology of the outbreak was inconclusive, it likely included AiV. Although the authors concluded this was the first documentation of AiV transmission by food in Europe, it is uncertain what role AiV played in these infections. The role 
of AiV as a human pathogen has been strengthened since then; 457 stool specimens from children hospitalized with acute diarrhea and 566 stool specimens from adults and children involved in 110 gastroenteritis outbreaks were screened for AiV by RT-PCR amplification of the genomic region of the $3 \mathrm{C}$ and 3D nonstructural proteins. ${ }^{55}$ The results show a low incidence of $\mathrm{AiV}$ in pediatric samples and mixed infections with other microbiological agents in some cases. From the outbreak survey, it appears that the presence of AiV is an indicator of mixed infections causing gastroenteritis outbreaks and AiV could be involved in half of the oyster-associated outbreaks; however, in two fecal samples from hospitalized children, AiV was the only microbiological agent detected among all of the known agents, such as HRV, AstV, adenovirus, $\mathrm{SaV}$, NoV, and bacteria. Since children typically do not consume oysters, there may be other vehicles for AiV transmission. This was confirmed in an outbreak of gastroenteritis in Germany where $\mathrm{AiV}$ was the only pathogen found excreted at concentrations as high as $10^{12}$ RNA copies per gram stool; no obvious food source was identified. ${ }^{60}$

\section{Middle East respiratory syndrome coronavirus}

MERS-CoV is a newly recognized virus occurring mainly in the Middle East. ${ }^{61}$ As of June 2014, 683 cases, including 204 deaths, have been reported to the World Health Organization from Iran, Jordan, Kuwait, Lebanon, Oman, Saudi Arabia, Qatar, United Arab Emirates, and Yemen. Human-to-human transmission seems limited to family and health care settings, but a recent study raises concerns that MERS-CoV could be transmitted by camel milk and its products. ${ }^{62}$ Dromedary camels in the Middle East and Africa are now thought to be the intermediate hosts for transmission of MERS-CoV from bats to humans because MERS-CoV-specific antibodies and RNA fragments are widespread in camels from Saudi Arabia, Egypt, Tunisia, Nigeria, and Kenya. From studies in Kenya and Saudi Arabia, MERS-CoV has been circulating in dromedary camels for at least 20 years, and young dromedary camels have lower seroprevalences and are more likely to carry infectious virus. ${ }^{63}$ Swabs from milking camels and milk from two locations in Qatar tested positive for MERSCoV RNA using real-time RT-PCR testing. Analysis of an outbreak of MERS-CoV infection in humans associated with a barn in Qatar in October 2013 found dromedaries and humans were infected with nearly identical strains of MERSCoV. ${ }^{62,64}$ Samples were obtained from 14 camels on October 17, 2013. MERS-CoV was detected in nose swabs from three camels by three independent RT-PCRs and sequencing.
The nucleotide sequence of an ORF1a fragment (940 nucleotides) and a $4.2 \mathrm{~kb}$ concatenated fragment were very similar to the MERS-CoV from two human cases on the same farm and from another human isolate (differed by one nucleotide sequence). Eight additional camel nose swabs were positive on one or more RT-PCRs, but could not be confirmed by sequencing. All camels had MERS-CoV spike-binding antibodies that correlated well with the presence of neutralizing antibodies to MERS-CoV. ${ }^{65}$ Another study in Saudi Arabia found extensive circulation of different genetic variants of MERS-CoV in camels and antibodies to MERS-CoV in samples from as early as the $1990 \mathrm{~s} .{ }^{62}$ Local camel milking customs do not include cleaning the udders before milking, allowing possible transfer of contamination from udders to milk. Milk could be contaminated by nasal secretions or feces from the camel, saliva of the calves allowed to suckle prior to milking to initiate the milk flow, or dirt from the bowl or hands of the milker. ${ }^{62}$ Raw milk is a potential source of infection from MERS-CoV; boiling milk before consumption could prevent transmission. A powdered camel milk product from the United Arab Emirates is now sold in Europe; such processing is likely to destroy any virus present. Antibodies to MERS-CoV were detected in serum and milk collected according to local customs from 33 camels in Qatar, April 2014. At one location, evidence of active virus shedding in nasal secretions and/or feces was observed for seven of 12 camels; viral RNA was detected in the milk of five of these seven camels. ${ }^{62}$ The presence of MERS-CoV RNA in the milk of camels actively shedding the virus warrants measures to prevent putative foodborne transmission of MERS-CoV.

Severe acute respiratory syndrome (SARS) is an enteric as well as a respiratory disease. ${ }^{66} \mathrm{SARS}-\mathrm{CoV}$ entered the human population through the preparation and consumption of food of animal origin, particularly civet cats, which contracted the infection from a bat reservoir. ${ }^{67}$ Some in Malaysia, Indonesia, and the People's Republic of China consider eating bat meat a delicacy or a cure for asthma, kidney ailments, and general malaise, and even bat feces are used in traditional Chinese medicine. ${ }^{67}$ Thus, coronaviruses may represent potential foodborne disease agents.

\section{Other viruses rarely transmitted through food Enteroviruses}

Enteroviruses (polioviruses, Coxsackievirus, and echoviruses) as a group have not been associated with foodborne illness, ${ }^{68}$ but polio virus has historically been linked to waterborne illness, and probably still is in endemic Pakistan. 


\section{Adenoviruses}

Adenoviruses are commonly associated with severe gastroenteritis in closed communities, but links to a foodborne source are infrequent. In Kansas in 2007, 64 cases reported eating sausages at a restaurant; ${ }^{69}$ although $\mathrm{HAdV}$ and NoV were isolated, no food vehicle was confirmed.

\section{Infectious $\mathrm{H} 5 \mathrm{NI}$ avian influenza virus}

Infectious $\mathrm{H} 5 \mathrm{~N} 1$ avian influenza virus has been cultured from duck meat, and the consumption of duck blood and direct contact with poultry has resulted in human infection. Those who had intestinal infection with H5N1 reported diarrhea as the sole first symptom of illness and other patients reported consumption of raw duck blood as their only possible exposure to poultry. ${ }^{70,71}$ Other studies have identified the infectious virus in stool samples, indicating the possibility of viral replication in the human digestive tract. ${ }^{72-74}$

\section{Nipah virus}

NiV may be transmitted through consumption of fruits contaminated with the saliva of fruit bats. ${ }^{75} \mathrm{NiV}$ infection was first recognized in a large outbreak of 276 reported cases in peninsular Malaysia and Singapore in 1998-1999. ${ }^{76}$ Most patients had contact with sick pigs. Patients presented primarily with encephalitis and 39\% died. The growth of large intensively managed commercial pig farms in Malaysia with fruit trees on the farm created an environment where bats could drop partially eaten fruit contaminated with NiVladen bat saliva into pig stalls. The pigs could eat the fruit, become infected with $\mathrm{NiV}$, and efficiently transmit virus to other pigs because of the dense pig population on the farms and frequent respiratory shedding of the virus among infected pigs. Farmers were infected directly from the sick pigs. In Bangladesh, NiV is transmitted from bats to people by ingestion of fresh date palm sap. Pteropus giganteus bats frequently visit date palm sap trees and lick the sap during collection; NiV can survive for days on sugar-rich solutions such as fruit pulp. In the 2005 Nipah outbreak in Bangladesh, the only exposure significantly associated with illness was drinking raw date palm sap. In outbreak investigations, villagers, especially children, commonly report consuming fruit that has been partially eaten by bats. ${ }^{76}$

\section{Control}

Because the burden of viral foodborne illness, particularly $\mathrm{NoV}$, is high, prevention and control strategies require serious consideration. One major cause of viral outbreaks is the infected food worker. ${ }^{16,75,77}$ The following measures are primarily aimed at foodborne NoV but apply equally to other enteric viral pathogens. . $^{10,21,35,78-85}$

- Clean and disinfect common environmental surfaces touched by many people.

- Emphasize thorough hand washing with approved hand disinfectants placed next to sinks.

- Reinforce strict personal hygiene for all individuals because asymptomatic colonized employees can transmit pathogens as well as those who are symptomatic.

- Display clearly visible signs for employees to wash their hands after toilet visits and before food consumption accompanied by frequent verbal and written reminders.

- Educate employees that if they feel gastrointestinal symptoms beginning, they must stop working immediately, and only resume work at least 2 days following remission of symptoms.

- Ensure certified kitchen managers supervise employees who handle food.

- Manufacturers, distributers, and retailers must have effect systems in place for timely recalls and improved trace back systems for suspected contaminated food.

- Develop specific interventions for reduction of the frequency of foodborne NoV outbreaks by focusing on food workers, produce, and shellfish.

- Improve viral diagnostics, including sequence analysis of predominant NoV genotypes, to identify chains of infection.

- Develop specific viral vaccines, antiviral drugs, and sanitizers effective against $\mathrm{NoV}$.

- Develop an efficient cell culture system, a robust animal model, and rapid and sensitive viral detection methods.

\section{Conclusion}

Nine viruses are described in association with foodborne illness (NoV, HAV, HEV, HRV, HAstV, SaV, AiV HAdV), with NoV causing most outbreaks, while food is not a major means of transmission for most other viruses. Poliomyelitis, once the scourge of any society that allowed their population to be in contact with sewage waters, is practically eliminated worldwide; at present, enteroviruses are not considered to be foodborne. MERS-CoV and other coronaviruses have zoonotic links but are not proven to cause foodborne outbreaks. Infectious $\mathrm{H} 5 \mathrm{~N} 1$ avian influenza virus has been responsible for illness relating to consumption of duck blood, and $\mathrm{NiV}$ was certainly linked to illness directly through consumption of fruit and palm tree sap in contact with bats and probably through bats themselves. However, both $\mathrm{H} 5 \mathrm{~N} 1$ and NiV have been transmitted more extensively through contact with food 
animals, eg, poultry and pigs. Recognition of enteric viruses as possible foodborne pathogens has been delayed since many of these viruses produce mild and often uninvestigated infections, are still not culturable and difficult to isolate, have symptoms similar to those caused by bacterial pathogens, and there are limited surveillance systems globally to detect viral pathogens. Thus, new foodborne viral diseases are likely to emerge in the future as diagnostic and surveillance methods improve. We should expect viruses to be foodborne if they have very low infectious doses, are excreted in high concentrations in stools or emesis of infected persons, and are found in food animals, including bush meat. Such viruses easily spread via the fecal-oral route, from person-to-person or to food and food contact surfaces, eg, one individual can trigger an outbreak by touching food or by simultaneously infecting coworkers in a restaurant. Workers in the harvesting, production, preparation, and serving of food, especially food requiring much handling, have been frequent transmitters of NoV and other viral infections; ${ }^{10,16,75,77}$ examples of such food are sandwiches, raw vegetables (especially leafy greens), berry fruits, sushi, hors d'oeuvres, layer cakes, and cake frosting. Treated sewage contains $10^{2}-10^{4} \mathrm{NoV}$ PCR detectable unit (pdu)/L and if discharged into surface water may reach areas where shellfish are harvested, ${ }^{86}$ and it is not surprising that molluscan shellfish, particularly oysters, have been implicated in outbreaks. The mechanism of virus entrapment in oysters may be more bound electrostatically to shellfish mucus or through attachment to zooplankton than straight filtering, as the viruses are too small to be filtered out by the gill filaments; more research is required to determine the actual mechanisms(s), and how they avoid being purged, digested, or otherwise destroyed by shellfish digestive processes. ${ }^{87} \mathrm{NoV}$ contributes the largest number of foodborne disease cases in countries where surveillance is sufficiently sophisticated to identify viruses, but there are many developing countries where there is no public health awareness of this pathogen. Since NoV and other enteric viruses are globally distributed, more foodborne viral illnesses arising from outbreaks are expected to be identified in more countries in the future. As the genetic types become better understood and diagnosed on a regular basis, we may see patterns among the outbreaks that indicate regional, host, food, or environmental vehicle preferences.

Adequate hand hygiene is the most effective prevention measure given that both ill and asymptomatic persons can transmit the viruses. Control and clean-up of contamination is achieved using chlorine-based compounds. ${ }^{88}$ Unfortunately, alcohol-based hand rubs have limited effectiveness against NoV and some other non-enveloped viruses, and are not permitted to be used in food settings by the US Food and Drug Administration. ${ }^{89}$ Although vaccines are available for HRV, and have reduced gastroenteritis in children, ${ }^{7}$ none as yet exist against NoV. The burden of NoV infection justifies continued efforts toward vaccine development and identification of specific groups for such interventions, eg, young children, the elderly, and possibly health care workers, travelers, and military personnel. ${ }^{90}$ For those viruses transmitted through contact with animals, eg, camels, poultry, pigs, bats, and bush game, care must be taken not to have direct contact without suitable precautions to avoid respiratory inhalation or oral ingestion of viral particles, and to cook meat thoroughly.

It is difficult to determine the significance of some viruses that may cause foodborne disease. The frequency of DNA sequencing in recent years has led to identification of new human and animal viruses, eg, MERS-CoV. While the pathogenicity of some newly characterized human viruses has been demonstrated, it remains unknown or controversial for other viruses, which may be commensal or pathogenic in only a very small fraction of infections. ${ }^{91}$ Multiple viruses may be isolated from diarrhea in persons with gastroenteritis. Genetic characterization of previously unknown viruses allows rapid design of the nucleic acid tests needed to determine their association with different medical conditions, their presence in different populations, and the design of antibody tests for determining seroprevalence. AiVs have been associated with gastroenteritis, often in mixed infections with other enteric viruses, and a high seroprevalence has been reported. Kobuviruses have been detected worldwide in both pigs and cows and were also associated with diarrhea. Detection of stool AiVs (sometimes called saliviruses) in many countries shows that these viruses are very widely disseminated..$^{91}$ The large degree of genetic diversity among some saliviruses based on partial three-dimensional sequencing may reflect the presence of multiple species and genotypes, which may exhibit different biological properties and antibody neutralization profiles. The association between salivirus shedding and diarrhea indicates that such infections may account for a significant fraction of the unexplained cases of diarrhea occurring worldwide. Research is needed to evaluate the efficacy of manure and water treatments to establish viral inactivation since water and treated manure can come into contact with shellfish and fresh produce. In this way, effective measures to prevent viral contamination at the primary level can be introduced rather than depending solely on preservation methods to establish a viral decline on foods. ${ }^{22}$ 
Another challenge is the determination of infectious doses of enteric viruses, including those that are foodborne, as a means of determining risk of infection and developing prevention and control measures. A paucity of existing information indicates these are very low, but more research is required to produce precise estimates. This may differentiate known pathogenic viruses such as NoV and HAV from the low infectious species, which may include HAstV and AiV, and identify which enteric viruses we should be most concerned about. The impact of new viral foodborne pathogens on susceptible populations, such as immunocompromised persons, the very young, very old, and those with comorbidities as opposed to the healthy adult population should also be determined. As Pintó et al have demonstrated for HAV, ${ }^{32}$ once doses and the amount of viral particles likely to be transferred to food by infected food handlers are known, it will become possible to determine the risk of illness from specific food items such as shellfish or berries more precisely. Once these viruses have become established in a community, elimination is difficult. There is a trend for peak exposure during the cooler and drier seasons in both temperate and tropical countries, at least for $\mathrm{HRV},{ }^{92}$ but the impact of seasonality needs to be explored for other enteric viruses.

Perhaps, the biggest concern is not widespread foodborne transmission, but the fact that this mode of transmission may favor cross-species infections that are not evident otherwise, with the potential for adaptation of viruses to humans, especially with the increasing pressure on the environment from population growth, allowing more contacts between humans and animals in biotopes that were previously non-existent or rare. ${ }^{93}$

\section{Disclosure}

The authors report no conflicts of interest in this work.

\section{References}

1. Koopmans M, Duizer E. Foodborne viruses: an emerging problem. Int J Food Microbiol. 2004;90:23-41.

2. Psychology of Medicine. Hepatitis A. Available from: http://monsterologist. blogspot.com/2014/12/hepatitis-a.html. Accessed January 16, 2015.

3. US Food and Drug Administration. Bad Bug Book. 2nd ed. Foodborne Pathogenic Microorganisms and Natural Toxins Handbook. Available from: http://www.fda.gov/Food/FoodborneIllnessContaminants/ CausesOfillnessBadBugBook/. Accessed January 16, 2015.

4. International Organization for Standardization. Microbiology of food and animal feed - Horizontal method for determination of hepatitis A virus and norovirus in food using real-time RT-PCR. Part 1: Method for quantification. Available from: http://www.iso.org/iso/catalogue_detail. htm?csnumber=55382. Accessed January 12, 2015.

5. Tam CC, Viviani L, Rodrigues LC, O'Brien SJ. The second study of infectious intestinal disease (IID2): increased rates of recurrent diarrhoea in individuals aged 65 years and above. BMC Public Health. 2013;13: 739-746.
6. Scallan E, Hoekstra RM, Angulo FJ, et al. Foodborne illness acquired in the United States - major pathogens. Emerg Infect Dis. 2011;17: 7-15.

7. Payne DC, Vinjé J, Szilagyi PG, et al. Norovirus and medically attended gastroenteritis in US children. $N$ Engl J Med. 2013;368: $1121-1130$

8. Thomas MK, Murray R, Flockhart L, et al. Estimates of the burden of foodborne illness in Canada for 30 specified pathogens and unspecified agents, circa 2006. Foodborne Pathog Dis. 2013;10:639-648.

9. Vaillant V, de Valk H, Baron E, et al. Foodborne infections in France. Foodborne Pathog Dis. 2005;2:221-232.

10. Hall AJ, Wikswo ME, Pringle K, Gould LH, Parashar UD; Division of Viral Diseases, National Center for Immunization and Respiratory Diseases, CDC. Vital signs: foodborne norovirus outbreaks - United States, 2009-2012. MMWR Morb Mortal Wkly Rep. 2014;63:491-495.

11. Cressey P, Lake R. Estimated incidence of foodborne illness. In: New Zealand: Application of Overseas Models and Multipliers. Client Report No FW11006. 2011. Available from: http://www.foodsafety. govt.nz/elibrary/industry/estimates-burden-foodborne-disease-2011. pdf. Accessed December 9, 2014.

12. Havelaar AH, Haagsma JA, Mangen MJ, et al. Disease burden of foodborne pathogens in The Netherlands, 2009. Int J Food Microbiol. 2012;156:231-238.

13. Adak GK, Meakins SM, Yip H, Lopman BA, O’Brien SJ. Disease risks from foods, England and Wales, 1996-2000. Emerg Infect Dis. 2005;11:365-372.

14. Belliot G, Lopman BA, Ambert-Balay K, Pothier P. The burden of norovirus gastroenteritis: an important foodborne and healthcarerelated infection. Clin Microbiol Infect. 2014;20:724-730.

15. Centers for Disease Control and Prevention. Norovirus: Trends and outbreaks. 2014. Available from: http://www.cdc.gov/norovirus/trendsoutbreaks.html. Accessed December 9, 2014.

16. Franck KT, Lisby M, Fonager J, et al. Sources of calicivirus contamination in foodborne outbreaks in Denmark, 2005-2011 - the role of the asymptomatic food handler. J Infect Dis. 2015;211:563-570.

17. Foodborne illness outbreak database. The Marler Clark Network. Available from: http://www.outbreakdatabase.com/. Accessed January 16, 2015.

18. Payne JK, Hall M, Lutzke M, Armstrong C, King J. Multisite outbreak of norovirus associated with a franchise restaurant - Kent County, Michigan, May 2005. MMWR Morb Mortal Wkly Rep. 2006;55: 395-397.

19. Ethelberg S, Lisby M, Böttiger B, et al. Outbreaks of gastroenteritis linked to lettuce, Denmark, January 2010. Euro Surveill. 2010;15: pii 19484.

20. European Food Safety Authority. The European Union summary report on trends and sources of zoonoses, zoonotic agents and food-borne outbreaks in 2012. EFSA J. 2014;12:1-312.

21. Bernard H, Faber M, Wilking H, et al. Large multistate outbreak of norovirus gastroenteritis associated with frozen strawberries, Germany, 2012. Euro Surveill. 2014;19:20-19.

22. Baert L, Debevere J, Uyttendaele M. The efficacy of preservation methods to inactivate foodborne viruses. Int $J$ Food Microbiol. 2009;131:83-94.

23. Wikswo ME, Cortes J, Hall AJ, et al. Disease transmission and passenger behaviors during a high morbidity norovirus outbreak on a cruise ship, January 2009. Clin Infect Dis. 2011;52:1116-1122.

24. United States Department of Agriculture. Hoffmann S, Anekwe TD. Making sense of recent cost-of-foodborne-illness estimates. Economic Research Service. Economic Information Bulletin No 118. 2013. Available from: http://www.ers.usda.gov/media/1204379/eib118.pdf. Accessed December 9, 2014.

25. Verhoef L, Koopmans M, van Pelt W, et al. The estimated disease burden of norovirus in The Netherlands. Epidemiol Infect. 2013;141: 496-506.

26. Lopman BA, Reacher MH, Vipond IB, et al. Epidemiology and cost of nosocomial gastroenteritis, Avon, England, 2002-2003. Emerg Infect Dis. 2004;10:1827-1834. 
27. Maritschnik S, Kanitz EE, Simons, E, et al. A food handler-associated, foodborne norovirus Gii.4 Sydney 2012 - outbreak following a wedding dinner, Austria, October 2012. Food Environ Virol. 2013;5: 220-225.

28. World Health Organization. Health Topics: Hepatitis. 2014. Geneva, Switzerland. Available from: http://www.who.int/topics/hepatitis/en/. Accessed December 9, 2014.

29. Advisory Committee on Immunization Practices (ACIP), Fiore AE, Wasley A, Bell BP. Prevention of hepatitis a through active or passive immunization. Recommendations of the Advisory Committee on Immunization Practices (ACIP). MMWR Morb Mortal Wkly Rep. 2006;55(RR7):1-23.

30. Lees D. Viruses and bivalve shellfish. Int J Food Microbiol. 2000;59: 81-116.

31. Halliday ML, Kang LY, Zhou TZ, et al. An epidemic of hepatitis A attributable to the ingestion of raw clams in Shanghai, China. J Infect Dis. 1991;164:852-859.

32. Pintó RM, Costafreda MI, Bosch A. Risk assessment in shellfishborne outbreaks of hepatitis A. Appl Environ Microbiol. 2009;75: 7350-7355.

33. Wheeler C, Vogt TM, Armstrong GL, et al. An outbreak of hepatitis A associated with green onions. N Engl J Med. 2005;353:890-897.

34. Gallot C, Grout L, Roque-Afonso AM, et al. Hepatitis A associated with semidried tomatoes, France, 2010. Emerg Infect Dis. 2011;17: 566-567.

35. Collier MG, Khudyakov YE, Selvage D, et al. Outbreak of hepatitis A in the USA associated with frozen pomegranate arils imported from Turkey: an epidemiological case study. Lancet Infect Dis. 2014;14 976-981.

36. Yugo DM, Meng XJ. Hepatitis E virus: foodborne, waterborne and zoonotic transmission. Int J Environ Res Public Health. 2013;10: 4507-4533.

37. Berto A, Martelli F, Grierson S, Banks M. Hepatitis E virus in pork food chain, United Kingdom, 2009-2010. Emerg Infect Dis. 2012;18: 1358-1360.

38. Said B, Ijaz S, Chand MA, Kafatos G, Tedder R, Morgan D. Hepatitis E virus in England and Wales: indigenous infection is associated with the consumption of processed pork products. Epidemiol Infect. 2014;142: 1467-1475.

39. Colson P, Borentain P, Queyriaux B, et al. Pig liver sausage as a source of hepatitis E virus transmission to humans. J Infect Dis. 2010;202: 825-834.

40. Tei S, Kitajima N, Takahashi K, Mishiro S. Zoonotic transmission of hepatitis E virus from deer to human beings. Lancet. 2003;362: 371-373.

41. Takahashi K, Kitajima N, Abe N, Mishiro S. Complete or near-complete nucleotide sequences of hepatitis E virus genome recovered from a wild boar, a deer, and four patients who ate the deer. Virology. 2004;330: 501-505

42. Said B, Ijaz S, Kafatos G, et al. Hepatitis E outbreak on cruise ship. Emerg Infect Dis. 2009;15:1738-1744.

43. Centers for Disease Control and Prevention. Rotavirus. Available from: http://www.cdc.gov/rotavirus/clinical.html. Accessed January 16, 2015.

44. Fletcher M, Levy ME. Foodborne outbreak of Group A rotavirus gastroenteritis among college students - District of Columbia, March-April 2000. MMWR Morb Mortal Wkly Rep. 2000;49:1131-1133.

45. Bosch A, Pintó RM, Guix S. Human astroviruses. Clin Microbiol Rev. 2014;27:1048-1074.

46. Gould LH, Walsh KA, Vieira AR, et al. Surveillance for foodborne disease outbreaks - United States, 1998-2008. MMWR Surveill Summ. 2013;62:1-34.

47. Rzezutka A, Cook N. Survival of human enteric viruses in the environment and food. FEMS Microbiol Rev. 2004;28:441-453.

48. Maunula L, Kaupke A, Vasickova P, et al. Tracing enteric viruses in the European berry fruit supply chain. Int J Food Microbiol. 2013;167: 177-185.
49. Nakagawa-Okamoto $\mathrm{R}$, Arita-Nishida $\mathrm{T}$, Toda $\mathrm{S}$, et al. Detection of multiple sapovirus genotypes and genogroups in oyster-associated outbreaks. Jpn J Infect Dis. 2009;62:63-66.

50. Iritani N, Kaida A, Abe N, et al. Detection and genetic characterization of human enteric viruses in oyster-associated gastroenteritis outbreaks between 2001 and 2012 in Osaka City, Japan. J Med Virol. 2014;86: 2019-2025.

51. Oishi I, Yamazaki K, Kimoto T, et al. A large outbreak of acute gastroenteritis associated with astrovirus among students and teachers in Osaka, Japan. J Infect Dis. 1994;170:439-443.

52. Oka T, Wang Q, Katayama K, Saif LJ. Comprehensive review of human sapoviruses. Clin Microbiol Rev. 2015;28:32-53.

53. Hall AJ, Lopman BA, Vinjé J. Sapovirus. In: Morris GJ, Potter M, editors. Foodborne Infections and Intoxications. 4th ed. Waltham, MA, USA: Academic Press; 2013.

54. Kobayashi S, Fujiwara N, Yasui Y, Yamashita T, Hiramatsu R, Minagawa H. A foodborne outbreak of sapovirus linked to catered box lunches in Japan. Arch Virol. 2012;157:1995-1997.

55. Ambert-Balay K, Lorrot M, Bon F, et al. Prevalence and genetic diversity of Aichi virus strains in stool samples from community and hospitalized patients. J Clin Microbiol. 2008;46:1252-1258.

56. Yamashita T, Sakae K, Tsuzuki H, et al. Complete nucleotide sequence and genetic organization of Aichi virus, a distinct member of the Picornaviridae associated with acute gastroenteritis in humans. JVirol. 1998;72:8408-8412.

57. Yamashita T, Sugiyama M, Tsuzuki H, Sakae K, Suzuki Y, Miyazaki Y. Application of a reverse transcription-PCR for identification and differentiation of Aichi virus, a new member of the Picornavirus family associated with gastroenteritis in humans. J Clin Microbiol. 2000;38:2955-2961.

58. Kitajima M, Hata A, Yamashita T, Haramoto E, Minagawa H, Katayama H. Development of a reverse transcription-quantitative PCR system for detection and genotyping of Aichi viruses in clinical and environmental samples. Appl Environ Microbiol. 2013;79:3952-3958.

59. Le Guyader FS, Le Saux JC, Ambert-Balay K, et al. Aichi virus, norovirus, astrovirus, enterovirus, and rotavirus involved in clinical cases from a French oyster-related gastroenteritis outbreak. J Clin Microbiol. 2008;46:4011-4017.

60. Drexler JF, Baumgarte S, de Souza Luna LK, Eschbach-Bludau M, Lukashev AN, Drosten C. Aichi virus shedding in high concentrations in patients with acute diarrhea. Emerg Infect Dis. 2011;17:1544-1547.

61. Centers for Disease Control and Prevention. Middle East Respiratory Syndrome. 2014. Available from: http://www.cdc.gov/coronavirus/ mers/. Accessed January 14, 2015.

62. Reusken CB, Farag EA, Jonges M, et al. Middle East respiratory syndrome coronavirus (MERS-CoV) RNA and neutralising antibodies in milk collected according to local customs from dromedary camels, Qatar, April 2014. Euro Surveill. 2014;19:pii 20829.

63. Corman VM, Jores J, Meyer B, et al. Antibodies against MERS coronavirus in dromedary camels, Kenya, 1992-2013. Emerg Infect Dis. 2014;20:1319-1322.

64. Haagmans BL, Al Dhahiry SH, Reusken CB, et al. Middle East respiratory syndrome coronavirus in dromedary camels: an outbreak investigation. Lancet Infect Dis. 2014;14:140-145.

65. Xia S, Liu Q, Wang Q, et al. Middle East respiratory syndrome coronavirus (MERS-CoV) entry inhibitors targeting spike protein. Virus Res. 2014;194:200-210.

66. Leung WK, To KF, Chan PK, et al. Enteric involvement of severe acute respiratory syndrome-associated coronavirus infection. Gastroenterology. 2003;125:1011-1017.

67. Lau SK, Woo PC, Li KS, et al. Severe acute respiratory syndrome coronavirus-like virus in Chinese horseshoe bats. Proc Natl Acad Sci US A. 2005;102:14040-14045.

68. Pasquinelli L. Enterovirus infections. Pediatr Rev. 2006;27:e14-e15.

69. Centers for Disease Control and Prevention. NORS Foodborne Outbreak Online Database (FOOD). Available from: http://wwwn.cdc.gov/ foodborneoutbreaks/Default.aspx. Accessed January 13, 2015. 
70. Apisarnthanarak A, Kitphati R, Thongphubeth K, et al. Atypical avian influenza (H5N1). Emerg Infect Dis. 2004;10:1321-1324.

71. Beigel JH, Farrar J, Han AM, et al. Avian influenza A (H5N1) infection in humans. $N$ Engl J Med. 2005;353:1374-1385.

72. de Jong MD, Bach VC, Phan TQ, et al. Fatal avian influenza A (H5N1) in a child presenting with diarrhea followed by coma. $N$ Engl J Med. 2005;352:686-691.

73. de Jong MD, Simmons C, Thanh TT, et al. Fatal outcome of human influenza A (H5N1) is associated with high viral load and hypercytokinemia. Nat Med. 2006;12:1203-1207.

74. Uiprasertkul M, Puthavathana P, Sangsiriwut K, et al. Influenza A H5N1 replication sites in humans. Emerg Infect Dis. 2005;11: 1036-1041.

75. European Food Safety Authority. EFSA Panel on Biological Hazards (BIOHAZ) scientific opinion on an update on the present knowledge on the occurrence and control of foodborne viruses. EFSA J. 2011;9:2190.

76. Choffnes ER, Relman DA, Olsen LA, Hutton R, Mack A, Improving Food Safety through a One Health Approach: Forum on Microbial Threats Board on Global Health. Washington DC, USA: Institute of Medicine; 2012.

77. Todd ECD. Food safety assurance systems: personal hygiene and employee health. In: Motarjemi Y, Moy GG, Todd ECD, editors. Encyclopedia of Food Safety. Waltham, MA, USA: Academic Press; 2014.

78. Vega E, Barclay L, Gregoricus N, Shirley SH, Lee D, Vinjé J. Genotypic and epidemiologic trends of norovirus outbreaks in the United States, 2009 to 2013. J Clin Microbiol. 2014;52:147-155.

79. Ahmed SM, Hall AJ, Robinson AE, et al. Global prevalence of norovirus in cases of gastroenteritis: a systematic review and meta-analysis. Lancet Infect Dis. 2014;14:725-730.

80. Guzman-Herrador B, Jensvoll L, Einoder-Moreno M, et al. Ongoing hepatitis A outbreak in Europe 2013 to 2014: imported berry mix cake suspected to be the source of infection in Norway. Euro Surveill. 2014;19:pii 20775.

81. Petrignani M, Verhoef L, Vennema $\mathrm{H}$, et al. Underdiagnosis of foodborne hepatitis A, The Netherlands, 2008-2010(1.). Emerg Infect Dis. 2014;20 (4):596-602.

82. McCarthy KS, Guntapong R, Thattiyaphong A, et al. Outbreak of norovirus gastroenteritis infection, Thailand. Southeast Asian J Trop Med Public Health. 2013;44:409-416.

83. Dicaprio E, Ma Y, Hughes J, Li J. Epidemiology, prevention, and control of the number one foodborne illness: human norovirus. Infect Dis Clin North Am. 2013;27:651-674.

84. Li J, Predmore A, Divers E, Lou F. New interventions against human norovirus: progress, opportunities, and challenges. Ann Rev Food Sci Technol. 2012;3:331-352.

85. Wadl M, Scherer K, Nielsen S, et al. Food-borne norovirus - outbreak at a military base, Germany, 2009. BMC Infect Dis. 2010;10:30.

86. van den Berg H, Lodder W, van der Poel W, Vennema H, de Roda Husman AM. Genetic diversity of noroviruses in raw and treated sewage water. Res Microbiol. 2005;156:532-540.

87. Provost K, Dancho BA, Ozbay G, et al. Hemocytes are sites of enteric virus persistence within oysters. Appl Environ Microbiol. 2011;77: 8360-8369.

88. Lopman B, Gastañaduy P, Park GW, Hall AJ, Parashar UD, Vinjé J. Environmental transmission of norovirus gastroenteritis. Curr Opin Virol. 2012;2:96-102.

89. Todd EC, Michaels BS, Holah J, Smith D, Greig JD, Bartleson CA. Outbreaks where food workers have been implicated in the spread of foodborne disease. Part 10: Alcohol-based antiseptics for hand disinfection and a comparison of their effectiveness with soaps. J Food Prot. 2010;73:2128-2140.

90. Hall AJ, Lopman BA, Payne DC, et al. Norovirus disease in the United States. Emerg Infect Dis. 2013;19:1198-1205.

91. Linlin L, Victoria J, Kapoor A, et al. A novel picornavirus associated with gastroenteritis. J Virol. 2009;83:12002-12006.
92. Levy K, Hubbard AE, Eisenberg JN. Seasonality of rotavirus disease in the tropics: a systematic review and meta-analysis. Int J Epidemiol. 2009;38:1487-1496.

93. Koopmans M. In: Choffnes ER, Relman DA, Olsen LA, Hutton $\mathrm{R}$, Mack A, Rapporteurs. Workshop on Improving Food Safety through a One Health Approach: Forum on Microbial Threats Board on Global Health. Washington, DC, USA: Institute of Medicine; 2012.

94. Barclay L, Park GW, Vega E, et al. Infection control for norovirus. Clin Microbiol Infect. 2014;20:731-740.

95. Ye M, Li X, Kingsley DH, Jiang X, Chen H. Inactivation of human norovirus in contaminated oysters and clams by high hydrostatic pressure. Appl Environ Microbiol. 2014;80:2248-2253.

96. Desai R, Hembree CD, Handel A, et al. Severe outcomes are associated with genogroup 2 genotype 4 norovirus outbreaks: a systematic literature review. Clin Infect Dis. 2012;55:189-193.

97. Siebenga JJ, Vennema H, Zheng DP, et al. Norovirus illness is a global problem: emergence and spread of norovirus GII.4 variants, 2001-2007. J Infect Dis. 2009;200:802-812.

98. Fino VR, Kniel KE. UV light inactivation of hepatitis A virus, Aichi virus, and feline calicivirus on strawberries, green onions, and lettuce. J Food Prot. 2008;71:908-913.

99. Caul EO. Viral gastroenteritis: small round structured viruses, caliciviruses and astroviruses. Part I. The clinical and diagnostic perspective. J Clin Pathol. 1996;49:874-880.

100. Favero MS, Bond WW. Disinfection and sterilization. In: Zuckerman AJ, Thomas HC, editors. Viral Hepatitis, Scientific Basis and Clinical Management. New York, NY, USA: Churchill Livingston; 1993.

101. Tjon GM, Coutinho RA, van den Hoek A, et al. High and persistent excretion of hepatitis A virus in immunocompetent patients. $J$ Med Virol. 2006;78:1398-1405.

102. Bae S-C, Park SY, Kim A-N, Oh M-H, Ha SD. Survival of hepatitis A virus on various food-contact surfaces during 28 days of storage at room temperature. Food Res Int. 2014;64:849-854.

103. McCaustland KA, Bond WW, Bradley DW, Ebert JW, Maynard JE. Survival of hepatitis A virus in feces after drying and storage for 1 month. J Clin Microbiol. 1982;16:957-958.

104. Sobsey MD, Shields PA, Hauchman FS, Davis AL, Rullman VA, Bosch A. Survival and persistence of hepatitis A virus in environmental samples. In: Zuckerman AJ, editor. Viral Hepatitis and Liver Disease. New York, NY, USA: Alan R Liss Inc.; 1988

105. Vasickova P, Psikal IP, Kralik P, Widen F, Hubalek Z, Pavlik I. [Hepatitis E virus: a review]. Vet Med-Czech. 2007;52:365-384. Czech.

106. Raj V, Smits SL, Pas SD, et al. Novel hepatitis E virus in ferrets, The Netherlands. Emerg Infect Dis. 2012;18:1369-1370.

107. Pesavento JB, Crawford SE, Estes MK, Prasad BV. Rotavirus proteins: structure and assembly. Curr Top Microbiol Immunol. 2006; 309:189-219.

108. Cox E, Christenson JC. Reoviruses: entry, assembly and morphogenesis. Pediatr Rev. 2012;33:439-447.

109. Bishop RF. Natural history of human rotavirus infections. In: Kapikian AZ, editor. Viral Infections of the Gastrointestinal Tract. 2nd ed. New York, NY, USA: Marcel Dekker Inc.; 1994.

110. Dennehy PH. Transmission of rotavirus and other enteric pathogens in the home. Pediatr Infect Dis J. 2000;19 Suppl 10:S103-S105.

111. Kurtz JB. Astroviruses. In: Kapikian AZ, editor. Viral Infections of the Gastrointestinal Tract. 2nd ed. New York, NY, USA: Marcel Dekker Inc.; 1994.

112. Monroe SS, Carter MJ, Herrmann JE, Kurtz JB, Matsui SM. 2000. Family Astroviridae. In: van Regenmortel MHV, Fauquet CM, Bishop DHL, et al, editors. Virus Taxonomy. San Diego, CA, USA: Academic Press; 2000.

113. Wang Q, Zhang, Z, Saif LJ. Stability of and attachment to lettuce by a culturable porcine sapovirus surrogate for human caliciviruses. Appl Environ Microbiol. 2012;78:3932-3940. 
114. ExPASy. Bioinformatics Resource Portal. Kobuvirus. Available from: http://viralzone.expasy.org/viralzone/all_by_species/652.html. Accessed January 16, 2015.

115. World Health Organization. WHO risk assessment. Middle East respiratory syndrome coronavirus (MERS-CoV), 2014. Available from: http://www.who.int/csr/disease/coronavirus_infections/ MERS_CoV_RA_20140424.pdf. Accessed January 13, 2015.

116. Lion T. Adenovirus infections in immunocompetent and immunocompromised patients. Clin Microbiol Rev. 2014;27:441-462.

117. UpToDate. Flomenberg P, Kojaoghlanian T. Epidemiology and clinical manifestations of adenovirus infection. Available from: http://www. uptodate.com/contents/epidemiology-and-clinical-manifestations-ofadenovirus-infection. Accessed January 16, 2015.
118. Wadell G, Allard A, Johansson M, Svensson L, Uhnoo I. Enteric adenoviruses. In Kapikian AZ, editor. Viral Infections of the Gastrointestinal Tract. 2nd ed. New York, NY, USA: Marcel Dekker Inc.; 1994.

119. Stalkup JR, Chilukuri S. Enterovirus infections: a review of clinical presentation, diagnosis, and treatment. Dermatol Clin. 2002;20: $217-223$.

\section{Publish your work in this journal}

Virus Adaptation and Treatment is an international, peer-reviewed open access journal focusing on the study of virology, viral adaptation and the development and use of antiviral drugs and vaccines to achieve improved outcomes in infection control and treatment. The journal welcomes original research, basic science, clinical \& epidemiological
Dovepress

studies, reviews \& evaluations, expert opinion and commentary, case reports and extended reports. The manuscript management system is completely online and includes a very quick and fair peer-review system, which is all easy to use. Visit http://www.dovepress.com/ testimonials.php to read real quotes from published authors.

Submit your manuscript here: http://www.dovepress.com/virus-adaptation-and-treatment-journal 